\section{ROTAS ATLÂNTICAS: O comércio de escravos entre Pernambuco e a Costa da Mina (c.1724-c.1752)}

Atlantic Routes: a slave trade route in the Atlantic between Pernambuco and the Costa de Mina (c.1724-c.1752)
Suely Cordeiro de

\section{ALMEIDA*}

(D) suealmeida.ufrpe@hotmail.com

*Universidade Federal

Rural de Pernambuco

Recife, PE, Brasil

\section{RESUMO}

Este trabalho expõe as primeiras conclusões alcançadas por uma pesquisa desenvolvida nos últimos três anos na qual procuramos contemplar o comércio atlântico de escravos para Pernambuco na primeira metade do século XVIII. Sob o crivo da História Social, buscamos criar um quadro inteligivel de como se articulavam os processos que abrangeram o comércio de gente, observando associados contratadores dos direitos de transportar escravos; os aspectos demográficos, logísticos e fiscais demandados pela Praça de Pernambuco. Por fim, analisamos a documentação de uma viagem realizada por uma Galera que saiu de Pernambuco e fez comércio em vários portos da Costa da Mina, retendo-se principalmente em Ajudá no ano de 1752.

Palavras-chave: Comércio, Escravidão, Navegação, Pernambuco, Costa da Mina

\begin{abstract}
This article presents the preliminary conclusions of a research that has been developed in the past three years regarding the slave trade to Pernambuco in the first half of the 18th century. Under the perspective of Social History, the goal was to create an intelligible framework of the articulation of the processes of people trade, observing the associated contractors of slave transport rights, and the demographic, logistical and fiscal aspects demanded by Praça de Pernambuco. Finally, an analysis is presented with the documented voyage of a Galera that left Pernambuco and made commerce in several ports of the Costa da Mina, being retained mainly in Aid in the year of 1752 ..
\end{abstract}

Keywords: Trade, Slavery, Navigation, Pernambuco, Costa da Mina 

disponível uma bibliografia extensa e de qualidade. Mas, a historiografia brasileira ainda é carente de trabalhos que tratem do fiscalismo ou tributação, consumo, comércio, monopólios, contratos e de negociantes em vários aspectos e, de forma especifica, quanto ao que correspondeu à mercancia de gente. A historiografia que trata da escravidão em Pernambuco é tímida, não avançando muito no tema e no recorte temporal específico sobre o qual tratamos neste artigo, embora hoje já se saiba que o porto de Pernambuco figura no quarto lugar dentre aqueles que na América mais recebeu cativos. ${ }^{1}$ Ao fim e ao cabo, acabamos concordando com Marcus Carvalho: "o comércio de escravos para Pernambuco é menos estudado do que para outros locais que recebera muito menos gente da África". ${ }^{2}$

O artigo que apresentamos a seguir tenta avançar sobre questões essenciais, embora dando os primeiros passos sobre a documentação selecionada. As fontes que utilizamos para a composição deste texto estão depositadas no Arquivo Histórico Ultramarino, na Biblioteca Nacional do Rio de Janeiro e nos Arquivos Nacionais da Torre do Tombo. Como este trabalho faz parte de um projeto maior que envolveu a Provedoria da Fazenda Real de Pernambuco, a documentação utilizada aqui incide mais sobre as fontes do Arquivo Histórico Ultramarino; no entanto, foi essencial a investigação nos demais acervos citados para que chegássemos até aqui. Quanto ao recorte temporal, escolhemos o ano de 1724 , por ser aquele em que há mais indícios disponíveis para o tratamento do tema, mas também por ser o ano em que primeiro se dá a arrematação do contrato da cobrança dos "Direitos dos escravos que vão de Pernambuco e Paraíba para as minas", ao mesmo tempo em que se passa a cobrar o contrato da dízima no porto de Pernambuco sobre toda a mercadoria que entra na capitania, intensificando a fiscalização. Já o ano de 1752 foi escolhido pelo fato de ser a data de uma escrituração detalhada de uma viagem entre a Costa da Mina e Pernambuco - o que nos dá subsídios para esclarecer aspectos importantes do processo de transporte de escravizados -, mas também porque se aproxima do período de fechamento do que chamamos de comércio livre, ou seja, da trata anterior à implantação de Companhia de Comércio de Pernambuco e Paraíba. ${ }^{3}$ A segunda metade do XVIII, já foi bem mais estudada e já esclareceu que os mecanismos de comércio serão transformados pelas intervenções pombalinas no reinado de D. José. Consideramos ser pertinente realizar uma reflexão que englobe as transformações fiscais, e que envolva as transformações da primeira metade do século XVIII para a segunda e adentre o XIX, com a chegada da família real; no entanto, não há espaço neste artigo para um debate tão amplo.

\section{Os Contratos}

Os comerciantes em Lisboa e seus capitais associavam-se ao comércio ultramarino. Eles estavam interessados no resgate de escravos, fossem da Costa da Mina ou de Angola, para retirar por pagamento de suas peças ouro das Gerais. A prática era antiga, desde os primórdios da colonização havia comerciantes portugueses associados a florentinos, genoveses e castelhanos. Eles, componentes da classe mercantil lisboeta, mediante concessão ou privilégio chegavam a manter exclusividade de produção ou de aquisição 
de mercadorias - quer metropolitanas, quer coloniais - para vendê-las alhures, como sal, sabão, couros, vinhos, escravos, etc. Eles controlavam os preços da produção até a distribuição no mercado. Para tanto, arrematavam contratos pessoalmente ou através de representantes em Lisboa no Conselho Ultramarino após 1724. Já nas conquistas portuguesas, os lances aconteciam nos leilões do mês de janeiro, estes dirigidos pelos provedores da Fazenda Real, prática normatizada por regimento desde 1548.

Mas o que era o contrato?

Contratação ou a ação de contratar mediante o estabelecimento de um contrato ou assento diz respeito à exploração de matérias-primas, à prática de comércio de mercadorias, ou à arrematação do privilégio da cobrança dos tributos e de rendimentos reais. Os contratadores foram arrendatários que, mediante condições estabelecidas nas cláusulas do instrumento contratual e acertos financeiros com a Fazenda Real, arrematavam o monopólio e a cobrança de impostos ${ }^{4}$. No século XVIII, havia exigência de que os contratadores junto ao fiador assinassem compromisso de saldar as dívidas com a Coroa, caso não pudessem honrar o contrato com os lucros auferidos do mesmo. Isso se fazia com a entrega de seus bens móveis e de raiz "havidos e por haver"5. Considerados sócios temporários da Coroa, assumiram uma posição social relevante em virtude da importância dos produtos transacionados, do montante do capital investido e da profunda interferência na vida socioeconômica da metrópole e seus domínios.

Ao Estado cabia garantir o funcionamento do sistema frente a estrangeiros e aos habitantes das conquistas, além da população metropolitana.

São os contratos do ultramar um dos principais socorros de que
se mantem e sustentam as conquistas de Portugal, ficando sempre
muita parte livre com que se pode enriquecer o Erário Régio que
poderá ser ainda maior quando for menor as despesas naquelas
partes (..... ${ }^{6}$

Os arrendamentos, monopólios e contratos foram solução para apertos financeiros. Eles estabeleciam sociedade temporária oferecida pela Coroa com a Fazenda Real para a exploração do comércio de um produto ou de serviço. O valor do contrato era definido no ato do leilão, pago em parcelas anualmente por três anos. As orientações a respeito dos leilões e arrendamentos estão dispostas para o Brasil no Regimento da Provedoria da Fazenda Real de 1548, e foram aplicadas nas diversas partes da conquista americana por muitas décadas, até que em 1724 foram transferidos para Lisboa e passaram a acontecer na casa do Conselho Ultramarino.

Nem todos os contratos foram transferidos imediatamente da administração da Fazenda Real para o Conselho Ultramarino. Em Pernambuco, o contrato da entrada dos negros na alfândega, oriundos da Costa da Mina e para auxílio da fortaleza do Ajudá só passaram ser leiloados em Lisboa em 1732. O provedor da Fazenda Real João do Rego Barros mandou pôr editais nos lugares públicos e costumeiros da vila de Santo Antônio do Recife de Pernambuco, pelos quais fez saber a todas as pessoas que sua majestade ordenou em 12.09.1731 que fossem mandados à Corte para arrematação no Conselho Ultramarino os contratos de entrada de negros da Costa da Mina na alfândega de Pernambuco. 
A praça comercial da capitania de Pernambuco já era traquejada no comércio de escravos, pois desde 1549 o primeiro donatário instou à Coroa que fossem trazidos a Pernambuco as primeiras peças. No entanto, embora seja longeva a experiência de mercancia na costa da África, pouco se sabe sobre suas conexões com Pernambuco. 0 fluxo mensal, os negociantes e suas práticas, entre outros aspectos, ainda carecem de estudos.

Entre as fontes depositadas no Arquivo Histórico Ultramarino encontramos uma relação do rendimento dos direitos dos escravos vindos para Pernambuco da Costa da Mina e Cacheu, na qual estão registrados os navios, mestres e valores dos direitos, além do quantitativo de escravos. Cabe destacar que esta relação de rendimentos é um fragmento de um livro de despachos da alfândega. Nossa amostragem (Quadro 1) engloba o ano de 1724, e nos permite ter uma ideia sobre o fluxo de entrada de cativos no porto de Pernambuco da vila do Recife. Todas as embarcações são ditas de nação portuguesa, embora a fonte não apresente o nome de seus proprietários nem detalhes sobre as pessoas escravizadas. Acrescentaram-se a esta relação as informações coletadas no site Trans Atlantic Slave Voyages, o que nos fez chegar a um quantitativo de 12 barcos, embora segundo as anotações da Provedoria da Fazenda de Pernambuco cheguem a 10 navios.

Os totais monetários arrolados não são correspondentes às somas realizadas. O total é de $5: 535 \$ 576$, as somas simples dos valores chegam ao montante de 3:511\$376. Foram incluídos os valores pagos na llha de São Tomé, bem como os de entrada na Paraíba. Se compararmos ao valor estabelecido pelo contrato dos direitos dos escravos que vão para as minas e que englobam Pernambuco e Paraíba em 1725, o valor é bem próximo, que era de seis contos de réis. No ano de 1724, entraram em Pernambuco 2.728 escravos pelas anotações da alfândega; e, se todos tivessem pagado direitos no porto de Pernambuco, a ordem de $3 \$ 500$ rs, como estabelece a fonte consultada chegaríamos ao montante de 9:898\$000 réis. Essa quantia torna o contrato muito interessante em termos de remuneração: se seis contos era o valor a ser entregue à Provedoria da Fazenda, restariam ao contratador três contos, oitocentos e noventa e oito mil réis em cada ano. É claro que estamos navegando nas águas, em parte, da suposição, e são necessários mais dados para chegarmos aos percentuais de lucro proporcionado pelo comércio atlântico de escravos.

E a Praça de Pernambuco, quais eram as suas dimensões?

\section{A praça do Recife}

Em Pernambuco, havia uma cidade e sete vilas: Olinda, cidade desde 1676, e as vilas Santo Antônio do Recife, Igarassu, Goiana, Sirinhaém, Porto Calvo, Alagoas e Penedo. As áreas que estavam interligadas ao porto do Recife podem ser compreendidas a partir da divisão eclesiástica, ou seja, as freguesias. Olinda e seu termo compreendiam oito freguesias, todas comandadas por capitães de ordenanças: Varge, São Lourenço, Nossa Senhora da Luz, Santo Antão, Santo Amaro de Jaboatão, Ararobá, Rodelas, Rio Grande do Sul. Já a vila de Santo Antônio do Recife compunha-se de três freguesias, todas circunscritas a seu termo: Santo Antônio do Cabo, Muribeca, Ipojuca. ${ }^{8}$ 


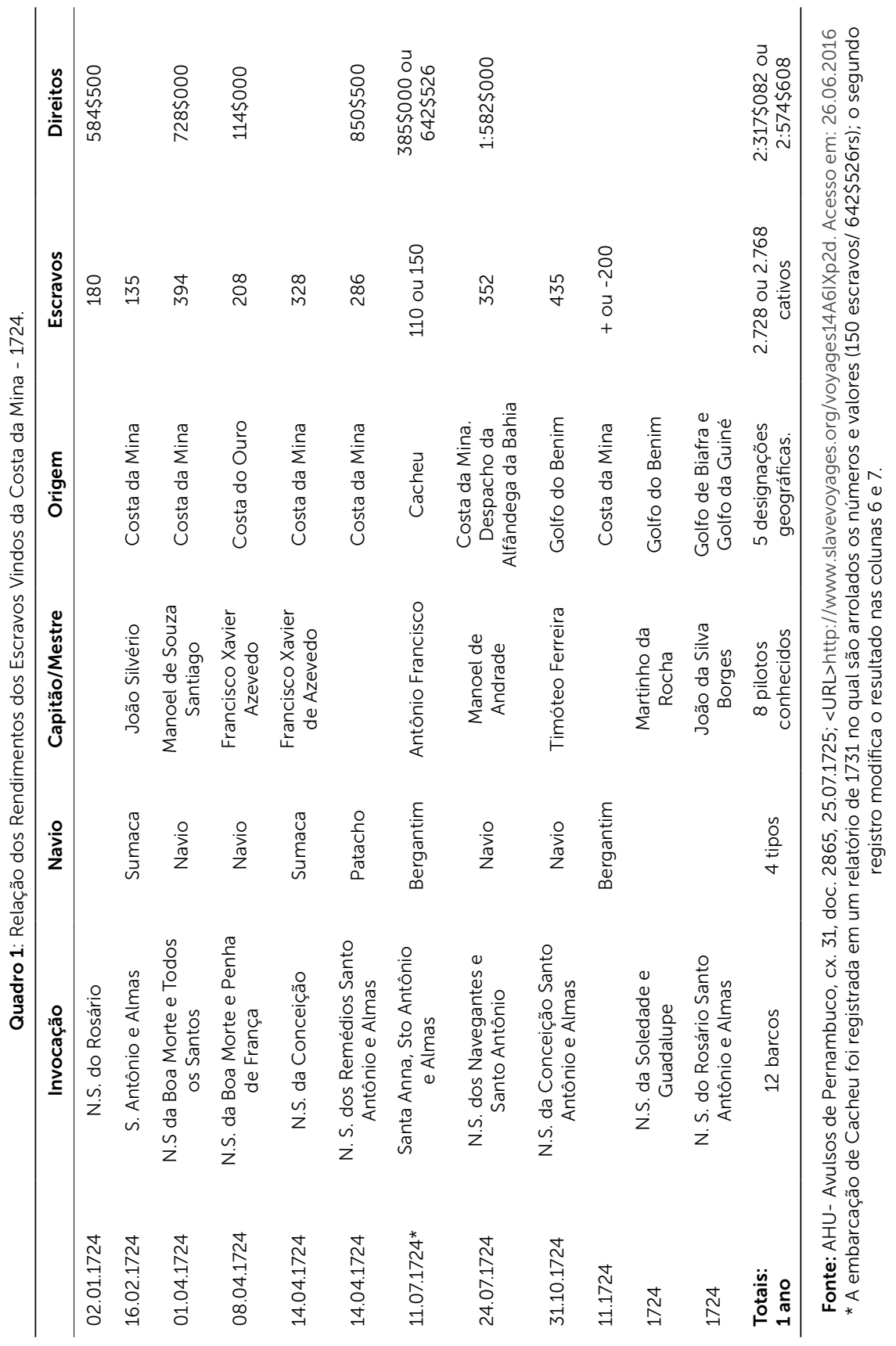


Segundo o governador de Pernambuco Dom Marcos de Noronha, aquele que produziu a memória intitulada Informação Geral da Capitania de Pernambuco de 1749, as ocupações da cidade de Olinda e da vila do Recife, espaços urbanos mais importantes da capitania, teriam as seguintes conformações: a freguesia de Santo Antônio do Recife possuía no bairro do Recife 653 fogos, nos quais habitavam 4.757 pessoas de comunhão. Já no bairro de Santo Antônio havia 1.368 fogos, habitados por 7.779. Os comungantes residiam em um total de 2.021 fogos, e contabilizavam 12.536 católicos, que se confessavam e participavam dos ofícios da fé periodicamente.

Já na freguesia de São Salvador da cidade de Olinda havia 612 fogos e 2.877 residentes. Essa freguesia englobava a da Boa Vista, que possuía 739 fogos e 3.098 habitantes. Na freguesia de São Pedro da cidade de Olinda havia 246 fogos e 1.213 moradores. Feitos os cálculos, tínhamos 1.587 fogos e 7.098 habitantes.

Somada a população dessas três freguesias centrais (entre o Recife e Olinda), computamos em torno de 19.634 pessoas e 3.680 fogos.

Observemos que a Boa Vista estava incorporada à jurisdição de Olinda, mas geograficamente estava próxima à freguesia de Santo Antônio do Recife. Se levarmos em consideração que essa proximidade incorporava a dinâmica da Boa Vista aos bairros de Santo Antônio e do Recife, teremos as demandas de mais 739 fogos e 3.098 pessoas. ${ }^{9}$ Se somarmos o total da Boa Vista à freguesia de Santo Antônio do Recife, teremos uma demanda total próxima ao porto de 2.760 fogos, habitados por 15.634 pessoas. Tais cálculos demonstram que a vila do Recife era mais populosa e cosmopolita se comparada com Olinda, não só demograficamente como também em dinâmicas comerciais, haja vista a integração do porto ao resto do complexo da vila. Em outras palavras, tudo acontecia no Recife.

Do interior da capitania, utilizando-se dos rios navegáveis ou através da navegação de cabotagem, tanto vindo do Norte quanto do Sul em direção ao porto do Recife circulavam em torno de 56 barcos, que carregavam caixas, principalmente de açúcar, rolos de tabaco, seda, escravos e os mais variados produtos, além de uma lanchinha que transportava apenas pessoas. Saiam do porto de Pernambuco só de vasos pertencentes a negociantes locais 17 embarcações, alguns poucos comerciantes possuindo mais de uma. Essas embarcações de maior calibre eram abastecidas no porto de todos os produtos necessários para uma travessia atlântica, indo à Costa da Mina resgatar escravos e no retorno a Pernambuco faziam chegar seu produto até as Minas Gerais. (Quadro 2)

As pequenas embarcações para transporte de produtos, fossem para carga e descarga ou para promover a circulação de pessoas, eram essenciais e tiveram sua capacidade avaliada baseada no número de caixas de açúcar que podiam transportar. Fechar o circuito do comércio atuando na descarga do produto foi fundamental para reter o controle integral do processo. Grandes e médios negociantes investiram nesta atividade como demonstra o quadro 3. 


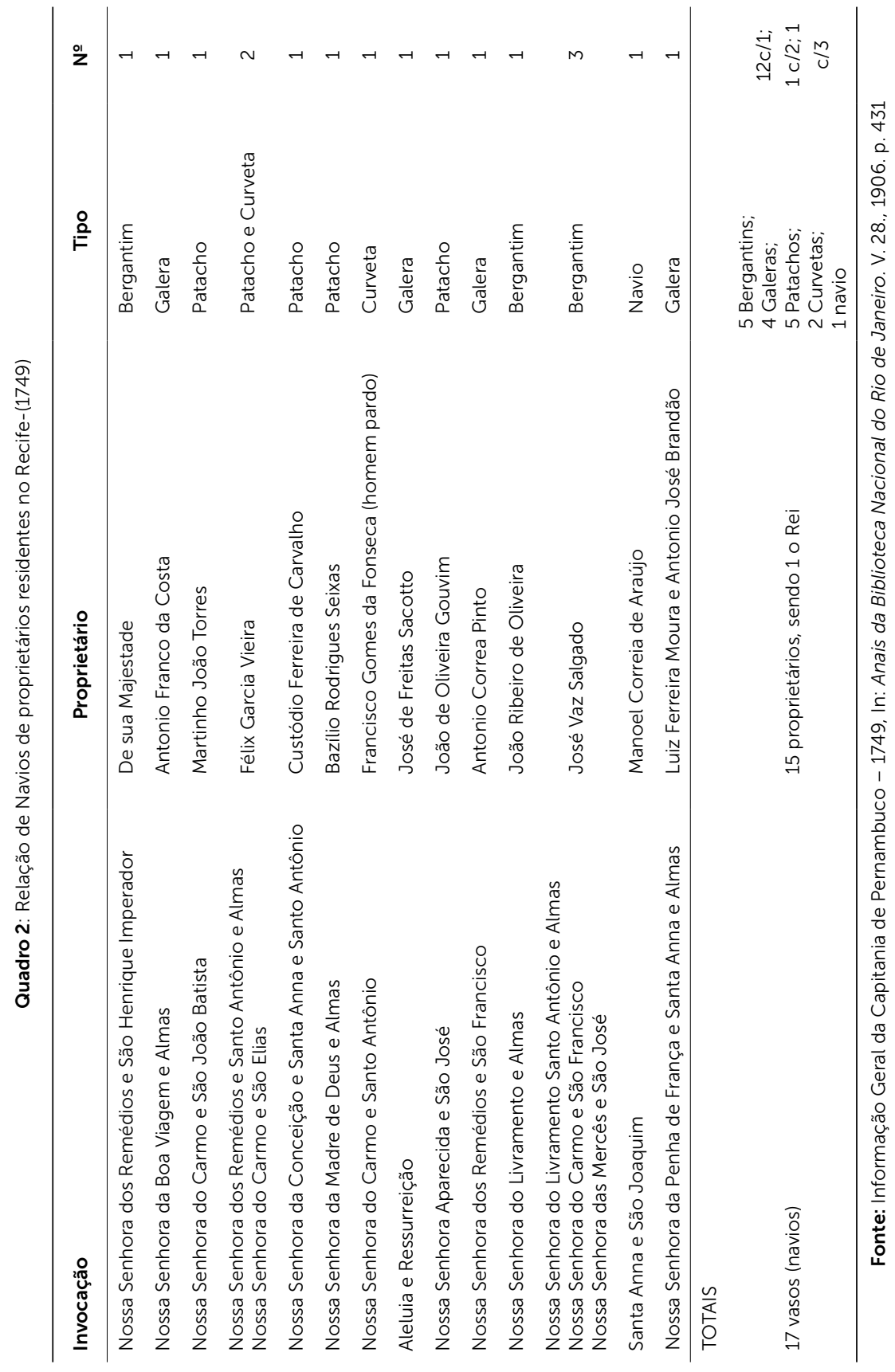




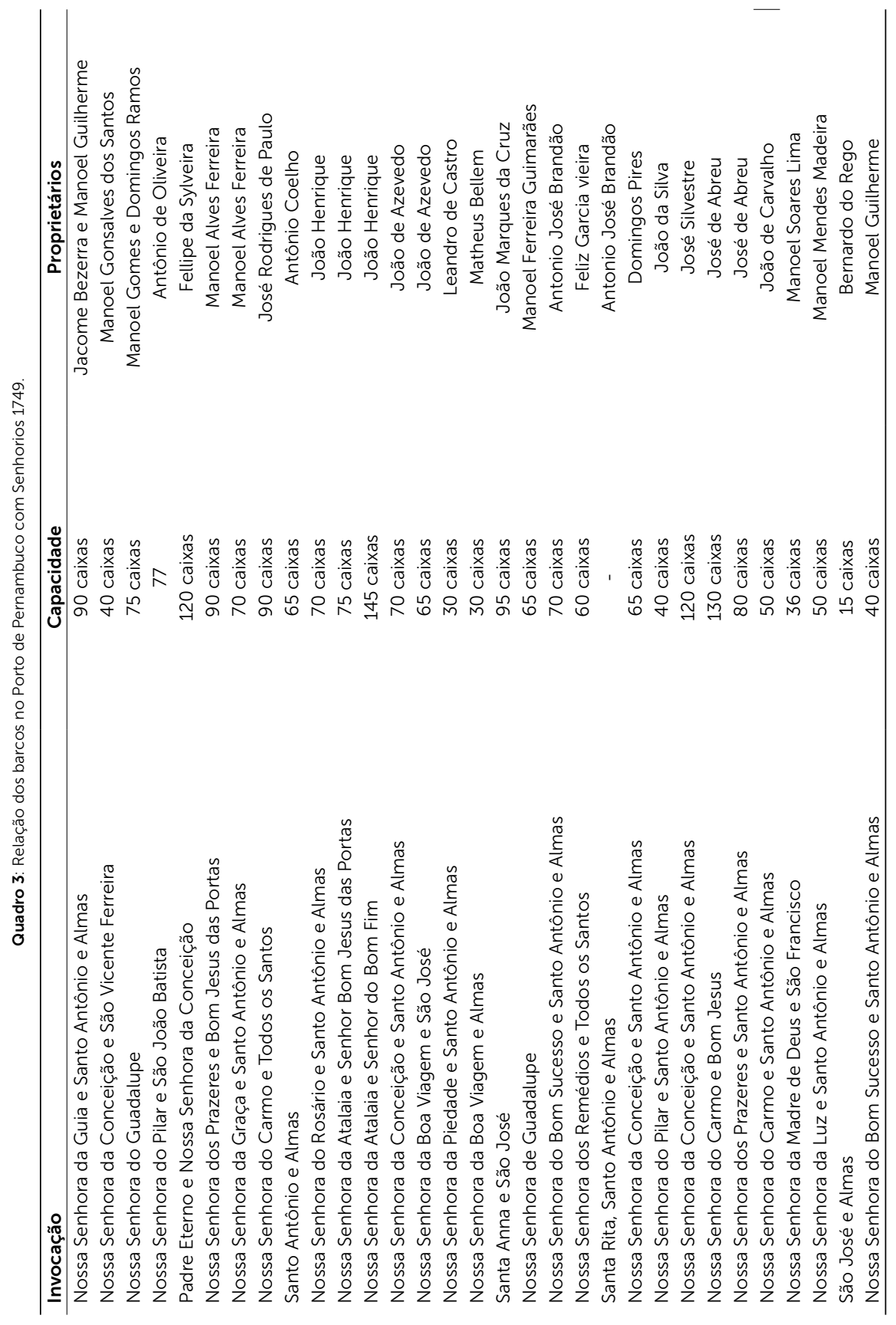




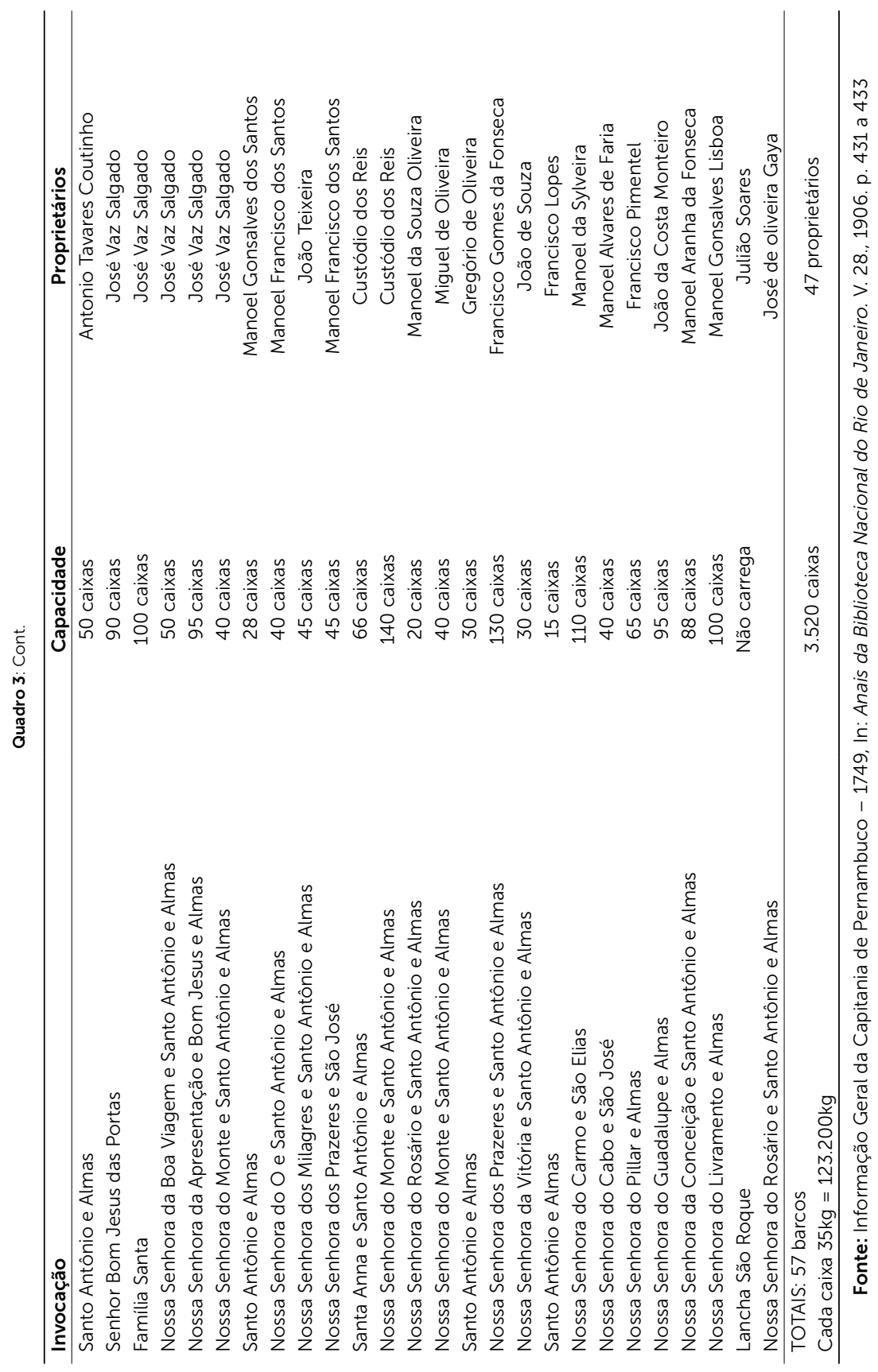


O que percebemos através dos quadros apresentados acima é que a Praça estava bem aparelhada para enfrentar as vicissitudes das travessias atlânticas, e para viabilizar o abastecimento da mão de obra escrava, em nosso caso, oriunda da África Ocidental.

Depois de vislumbrarmos a essa praça e suas possibilidades, voltemos aos contratos. Eles foram arrematados na Provedoria da Fazenda de Pernambuco, mesmo depois de 1724, pois só foi a partir de 1731 que o provedor João do Rego Barros mandou pôr editais nos lugares públicos costumeiros da vila de Santo Antônio do Recife, pelos quais fez saber que o contrato da entrada de "negros nas alfândegas que vêm da Costa da Mina e que de presente é administrado pela fazenda real" foi mandado à Corte e à cidade de Lisboa para ser leiloado no Conselho Ultramarino. Identificamos um comerciante que, por longo tempo estabelecido na Praça do Recife, passou à Corte a arrematar contratos para administração de direitos de escravos oriundos da Costa da Mina. Foi José de Freitas Sacoto, que já devia mercadejar neste segmento há anos, inclusive como procurador de comerciantes lisboetas. Ele participou do negócio até 1752, pagando à Coroa anualmente quinhentos mil réis pelo contrato dos Direitos de $1 \$ 000$ rs por escravo na entrada da alfândega de Pernambuco para a fortaleza de Ajudá, e um conto e duzentos mil réis anuais pelo contrato dos Direitos de 3\$500rs por escravo na entrada da alfândega de Pernambuco. Aos envolvidos nos contratos a não especialização foi o caminho percorrido, embora alguns tenham optado por não atuar no "comércio das almas". Estes negociantes apostaram nos mais diversos ramos, com o intuito de promover a cobertura de um investimento que se tornasse deficitário. As redes de relações foram essenciais. Localmente, investiram na organização de todas as atividades interligadas à execução dos contratos, pois precisavam manter bom fluxo de peças para que houvesse boa arrecadação, tudo tecido junto a comissários, procuradores e demais aliados associados para mover a engrenagem do comércio. As vicissitudes da execução levaram muitos negociantes/contratadores a se envolverem no fretamento de navios para transporte de escravos. As informações colhidas demonstram que, em um mesmo período, havia procuradores diversos representando contratadores diversos na Praça do Recife envolvidos no comércio de escravos.

No rol dos contratadores de grossos cabedais que arrematavam no Conselho Ultramarino estava Jerônimo Lobo Guimarães. Ele já foi referido por vários pesquisadores quando envolvido com a mercancia da Bahia, do Rio de Janeiro, e nas Minas arrematando variados contratos. Também atuou em Pernambuco entre 1725 e 1727 nos contratos dos Direitos dos escravos que vão de Pernambuco e Paraíba para a Minas. Foi um dos maiores contratadores que, na primeira metade do século XVIII, conduziu escravos para as Minas, arrematando nos leilões do Conselho Ultramarino desde 1724. Era morador no Cais de Santarém em Lisboa (LIBÂNIO, 2013, pp. 116-117). Sabemos que fretou a corveta Santa Ana e São Joaquim, pedindo permissão para os barcos resgatarem escravos na Costa da Mina. Não só ele mais vários negociantes lisboetas fecharam o circuito dos negócios envolvendo os seus contratos negreiros.

Os escravizados que saiam de Pernambuco por mar para as Minas pagavam $9 \$ 000$ réis de direitos, e deveriam seguir com uma guia ou passaporte que comprovasse o pagamento, assinada pelo contratador, procurador ou administrador do contrato de forma individual (LIBÂNIO, 2013, pp. 116-117). Os contratos em suas cláusulas estabeleciam 
como deveriam ser cobrados os direitos, flexibilizando inclusive os valores que deveriam ser arrecadados. Com a chegada de um negreiro no porto, aqueles que representavam o "negócio de carne humana" na Praça de Recife deveriam estar presentes, para tomar nota dos custos, organizar o desembarque dos cativos, que no porto do Recife era feito por lanchas pertencentes a particulares, pagar os direitos alfandegários conforme o caso, conduzi-los aos abrigos/quarentenas para as primeiras providências.

Esses passaportes deveriam ser apresentados dentro de 15 dias após a chegada ao provedor da Fazenda Real. As anotações eram feitas no livro dos registros, para evitar que a mesma guia fosse usada para introduzir outros escravos. Para as Minas, era terminantemente proibido que escravos fossem levados sem o pagamento e sem a guia, à exceção dos que se destinassem ao serviço junto a fazendeiros e roceiros e fossem ficar pelo caminho. Qualquer escravo que não estivesse devidamente documentado seria confiscado, e toda denúncia feita garantia ao denunciante a terça parte da arrecadação, em valores (dinheiro e/ou ouro), ou em peças (escravos) (LIBÂNIO, 2013, pp. 116-117). Um exemplo do quanto essa atividade era complexa é o caso que envolveu José de Sá Rosa. O relato esclarece que uma sumaca cujo piloto foi Manuel de Souza Santiago arribou na Bahia carregada como 209 escravos vindos da Costa da Mina, e que por cabotagem pretendia ir até o Rio de Janeiro. O barco levava escravos de sete remetentes, e haviam pago direitos da ordem de $4 \$ 500$ réis por cabeça, o que podiam comprovar. Se estes escravos descessem até às Minas, ainda deveriam ao fisco mais $4 \$ 500$ réis cada, pois o valor do contrato era de $9 \$ 000$ por peça se fossem por mar, como já foi dito. A arribada na Bahia gerou um processo sobre se os direitos deveriam ser pagos mais uma vez ao contratador soteropolitano. Bem que o consignatário dos escravos poderia ter a pretensão de no porto do Rio de Janeiro nada mais pagar, enviar os escravos para as Minas e embolsar $50 \%$ do valor do fisco devido, pois os valores dos direitos neste porto podiam variar, ora pagando-se $4 \$ 500$ ora $9 \$ 000$ réis. Todavia, a arribada na Bahia não interrompeu só a viagem, mas também desagregou a carga e inviabilizou o projeto, pois os escravos foram sendo vendidos lá mesmo, sem pagar mais nada, enquanto era esperada uma decisão na Justiça. Como é perceptível pelo exemplo, essa atividade, que era altamente rentável, foi vigiada por mil olhos. O fluxo de entrada de barcos negreiros oriundos da Costa da Mina no porto de Pernambuco era significativo. Tal situação levou a câmara do Recife em 1724 a fazer uma representação sobre a carestia e carências de mantimentos provocadas por serem "muitas as embarcações e continuadas viagens feitas a Costa da Mina". Para minorar o problema, D. João V expediu uma lei que obrigava todos que mandassem embarcações à Costa da Mina a manterem seus escravos trabalhando na produção de farinha para o abastecimento de seus barcos, sem onerar a oferta de viveres para a população local. A correspondência enviada pela câmara e a pronta providência tomada pelo monarca, nos faz perceber que uma boa parte das ações comerciais da Praça voltavam-se para o comércio de gente, volume que é possivel mensurar através da prestação de contas feita pelo provedor da Fazenda Real, João do Rego Barros à Coroa em 1732. Ele fez um levantamento das entradas de negreiros no porto do Recife entre os anos de 1722 e 1731, somente de embarcados na Costa da Mina, que apresentamos no quadro 4. 


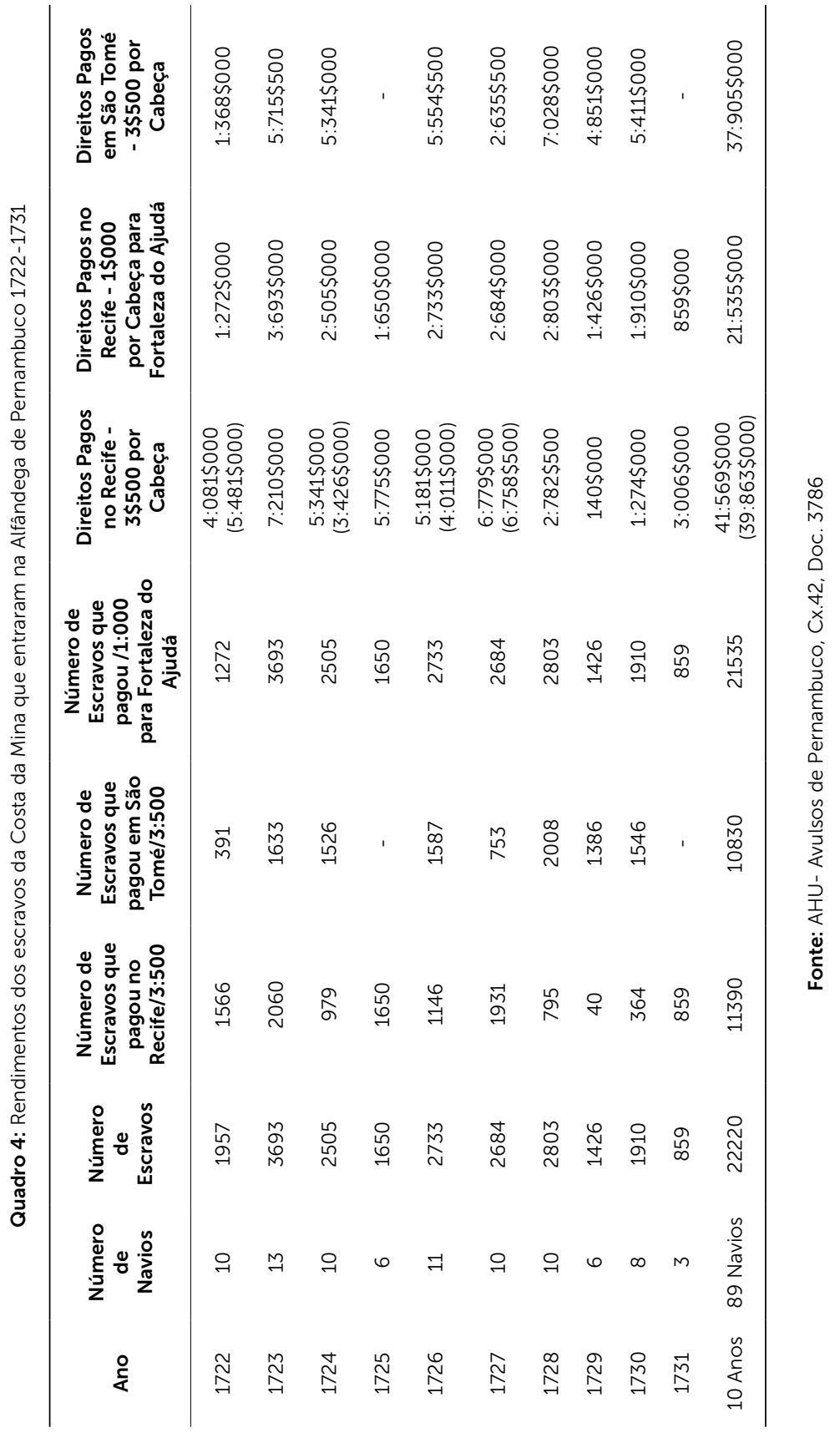


A história desse comércio é difícil de ser contada para Pernambuco. A navegação é constante; porém, é pouco documentada e eivada de ações individuais, ou feita por pequenos grupos organizados, às vezes, para cada viagem. Navios portugueses saídos das ilhas e de vários lugares do Brasil se entrecruzaram com barcos ingleses, franceses, holandeses de várias carreiras em variados portos, constituindo-se o Atlântico um lugar de conexão, mas também o não lugar por ser a via de fuga para múltiplos destinos. Pelos dados expostos no quadro acima, é possível perceber que a navegação é constante, embora vá entrando em declínio para meados do Setecentos. Para que se tenha uma noção mais clara do fluxo, será preciso compará-lo com o oriundo do porto de Luanda no mesmo período.

Entre os contratadores que arremataram contratos mais circunscritos geograficamente a Pernambuco está José de Freitas Sacoto, ${ }^{10}$ um dos comerciantes mais velhos atuantes na Praça de Pernambuco. Nos anos cinquenta do Setecentos, ele surge como arrematante, mas pode ter iniciado suas atividades de negreiro como procurador. Poderia ter sido o responsável pela cobrança dos direitos de introdução dos cativos no porto do Recife, e desta forma ter aprendido os meandros do ofício por décadas; depois, ele mesmo passou a ser um arrematante.

Ele nasceu em 1682, sendo natural do bispado de Coimbra e de família de lavradores e negociantes. Foi considerado um mercador de grosso trato, desenvolvendo suas atividades no comércio de escravos, inclusive possuindo navio próprio, a Galera Aleluia da Ressurreição e Almas. As fontes indicam que chegou a Pernambuco em 1699, portanto aos 17 anos. Realizou um processo de inserção social significativo, participando de instituições como Ordem Terceira do Carmo, Santa Casa de Misericórdia do Recife e Familiar do Santo Ofício. Seus bens chegavam a 50 mil cruzados, sendo referido como homem de negócio grosso e avultado, "negociando com a Corte e a Costa da Mina, emprestando dinheiro e com navios próprios" (MELLO, 1981, pp 151-189; SOUZA, 2012, pp 477-478).

De fato, entre 1750 e 1752 ele arrematou dois contratos para cobrança de direitos - o de 1 \$000rs para fortaleza do Ajudá, e o de $3 \$ 500$ rs por entrada de escravo na alfândega de Pernambuco, como já foi explicado acima; e, completando o circuito, vamos encontrá-lo embrenhado no comércio de gente enfrentando os riscos e intempéries da travessia do Atlântico, mas não sozinho, associado a consignatários e comerciantes da Costa da Mina na África Ocidental. Sua atuação na mercancia e na cobrança dos direitos dos escravos no porto do Recife deve lhe ter trazido vantagem considerável frente a seus concorrentes, principalmente frente ao processo de cobrança de direitos dos escravos na Alfândega de Pernambuco e São Tomé. Pela ordem processual dos negócios que as fontes nos deixam perceber, no porto de São Tomé, os negreiros teriam que pagar os direitos para realizar aguada. É um processo antigo, e a documentação referente a Pernambuco nos leva para o princípio do século XVIII. Em 1710, a Provedoria da Fazenda Real de Pernambuco foi instada a remeter os direitos cobrados em São Tomé para Lisboa. O mecanismo se constituía no envio de letras seguras para serem pagas no Conselho Ultramarino em ouro. Estas letras foram compradas por vários homens de negócio da Praça do Recife, chegando-se ao valor total de 9:416\$159. ${ }^{11}$ Mas nem sempre os direitos eram enviados em letras; algumas vezes, a Coroa exigia que fosse em ouro em barras e/ou em moedas e açúcar de boa qualidade. ${ }^{12}$ Todavia, as regras deste comércio eram sempre mutantes, pois percebemos que barcos 
equipados, mas avulsos, navegavam na costa em lugares como Cacheu, chegando até Geba (uma povoação) e Bissau com mercadorias novas, pagando direitos em Cabo Verde. Foi o caso de um navio cujo capitão foi Domingos Muniz, que saiu da região com 160 escravos. $^{13}$

A Galera Aleluia da Ressurreição e Almas, pertencente a Sacoto, pagou os direitos da carga ao contratador do contrato dos direitos dos escravos na llha de São Tomé, e foi através dos papéis apresentados pelo capitão do navio e consignatário da carga, José Francisco da Rocha, que tivemos conhecimento do desenrolar de todo o processo vivido por quem adquiria cativos nos portos da África Ocidental. José Francisco da Rocha fez anotações detalhadas dos negócios que realizou na costa africana, possibilitando ao historiador um olhar sobre o cotidiano do trato, o que permite dirimir dúvidas e mergulhar nos detalhes.

\section{A galera de José de Freitas Sacotto e uma viagem à Costa da Mina}

No porto da ilha de São Tomé no ano de 1752, foi registrada a entrada da Galera Aleluia da Ressurreição e Almas, pertencentes a José de Freitas Sacotto. Sua viagem teve início na capitania de Pernambuco, onde foi carregada e consignada a José Francisco da Rocha. Levava em seu interior uma carga composta de rolos de tabaco (2.267), peças de seda (1), côvados de seda (1.733), peças de pânicos (1.500), ancoras (122), pipas (18) e barricas de aguardente (2). Carga valiosa e adequada à empreitada. ${ }^{14}$

Todos esses produtos tinham sentido e destino certo numa viagem à costa africana ocidental. José Francisco da Rocha, consignatário de José de Freitas Sacoto, conhecia o passo a passo de como garantir as trocas de forma rentável naquelas plagas. Ele havia estabelecido relações bem fundamentadas com os negociantes que se distribuiam nos portos da Costa da Mina, articulações essenciais para o sucesso de uma viagem. Sua estratégia de negociação seguia a metodologia de estabelecer acordos e trocas de per si em cada porto em que a galera fundeava. As informações que nos deixou fez aparecer os mais variados personagens envolvidos no comércio mais lucrativo da Era Moderna, que foi o de gente. Eles estão conectados ao processo de trocas, como ferramentas indispensáveis para fazer funcionar o comércio das almas. ${ }^{15}$

Durante o ano de 1752, a galera viajou de porto em porto na Costa da Mina levando o consignatário a estabelecer acordos e negócios entre trocas, despesas e pagamento de taxas. Em Cabo Lahû, chegou a 11 de julho e lá despendeu de sua valiosa carga 4 rolos de tabaco por uma peça; e pelos serviços de um língua no gran Maçame mais um rolo. Mas, logo na chegada, iniciou-se a prática de trocar os produtos oriundos do Brasil, coloniais ou não, por produtos comerciados por europeus na Costa da Mina, para atender ao gosto e às necessidades locais. Na primeira parada, foram trocados rolos de tabaco e côvados de seda por frasqueiras de genebra com holandeses, e por ouro no pequeno e no gran Massame. ${ }^{16}$

No Castelo da Mina, a partir de 26 de julho entregou ao fiscal 11 rolos de tabaco; ao fiscal do Amaral, provavelmente um dos mandatários do local, 128 côvados de seda, operação que classificou como costumeira. Por quartiamento ou daxa dos 1.600 rolos, que era o total da carga, pagou 121 rolos de tabaco e mais 195 côvados de seda. ${ }^{17}$ Aos Bombas, para não refugarem o tabaco, pagou 1 rolo; ao Vaza, pela pedra e lastro para aguada, pagou mais 
3 rolos. Trocou côvados de seda por búzios e pânicos. ${ }^{18}$ Já para os escravos que estavam embarcados comprou azeite e malagueta, e gastou mais 4 rolos. Deu mais 2 rolos para aluguel de uma casa e sustento de todos. ${ }^{19} \mathrm{Um}$ navio negreiro possuía espaço interno bem delimitado para o acondicionamento da carga. Sua divisão se dava em três níveis. Assim, considerando-se de baixo para cima no porão, tínhamos espaço para armazenamento de água e víveres; na falsa coberta, eram armados os bailéus e acondicionados os cativos/as; e, por fim, no convés principal ficava a tripulação (RAMBELLI, 2013, p. 203). Os escravos eram transportados como "cargas vivas", um peso móvel a bordo. Existia separação entre os sexos e idade. Havia uma preocupação em controlar a distribuição a bordo, não só para evitar revoltas mas para preservar a vida da carga. O acondicionamento dos escravizados tinha o objetivo de garantir oxigênio para todos; assim, as medidas dos bailéus adequavamse ao tamanho e ao peso das pessoas. Nos porões, procurava-se armazenar água em quantidade mais ou menos de 2,8 litros por pessoa, mais biscoitos, arroz, favas, azeite, pólvora e munição para canhões, e por fim cordas (RAMBELLI, 2013, p. 203). Era realmente uma organização extremamente disciplinada, que permitia abarcar e realizar um processo extremamente complexo que entremeava o navio, o fazer humano e a natureza e seus caprichos.

Em uma sequência de tratados nos anos de 1641, 1661 e 1669, o comércio português estava proibido por toda a área que os Países Baixos considerasse seu território na Guiné que ia da Costa da Malagueta até o Benim. No forte da Mina, pagava-se 10\% da carga. Os portugueses e "brasílicos" (ALENCASTRO, 2000, p.28), pagando as taxas exigidas, poderiam comercializar com produtos oriundos do Brasil, o que levava os navios a realizarem trocas por produtos locais, europeus e/ou asiáticos para concluírem o negócio da compra de escravos. A Galera Aleluia da Ressurreição e Almas chegou de Pernambuco com uma carga composta de um número mínimo de produtos, predominando entre eles o tabaco em rolos e côvados de seda; todavia, nos portos em que fundeou, foi realizando trocas que possibilitaram ampliar o leque de negociações, ou seja, constituiu uma cesta diversificada para agradar aos negociantes e às populações locais.

Alberto da Costa e Silva aponta para a prática dos navios saídos do Brasil, de viajarem em princípio ao forte da Mina para pagar o tributo, evitavam o risco de apresamento, e depois velejavam ao longo do litoral, explorado tudo o quanto pudessem e o que seus batéis e galeotas permitissem, adentrando a furos, rios e lagunas ao longo da costa (SILVA, 2004, p. 44).

No dia 04 de agosto, a galera chegou a Anamabû. Nessa praça, o tabaco e a seda foram os produtos que predominaram nas trocas. Foram permutados por búzios, ancoras de genebra, barras de ferro, peças de lenços grossos, caixas de cachimbos, sarça, algodão vermelho, riscado, panos brancos, chitas e escravos. Os agentes que participaram da trata comercial e que tinham estabelecimentos em terra, foram anotados pelo consignatário com as seguintes denominações: um capitão holandês, um inglês entre outros, compondo uma cesta diversificada de produtos, ao mesmo tempo em que adquiria escravos. Seguiram rapidamente para Acara no dia 08 de agosto, comprando cativos e passando para o Popo já no dia 16 do mesmo mês. Uma viagem feita com rapidez para fugir às mais variadas pressões, como roubos, apresamentos e doenças. Um outro ponto importante a salientar 
eram os perigos constantes para um capitão e seu navio, como se verem envolvidos em meio a guerras entre os soberanos locais. Uma fatalidade deste naipe poderia acarretar a perda da carga, dos barcos, a prisão por longos anos, e até a vida (PARÉS, 2013).

Cada parada representava perdas de dinheiro e vidas entre a marujada e a escravaria, sem contar o perigo das revoltas e motins. As febres e diarreias eram outro terror, o que fazia os comandantes passarem o menor tempo possivel em cada porto. Alberto da Costa e Silva estima uma média de 20 dias, mas a galera Aleluia da Ressurreição e Almas passou menos, como demonstra o quadro abaixo. ${ }^{20}$

As anotações de José Francisco Rocha entre Anamabû, Acara e Popo podem ser organizadas em um quadro elucidativo, através do qual é possível saber dia, local e número de escravos adquiridos. Esclarece ainda sobre os produtos que foram transacionados, sobre as especificidades das preferências locais por artigos, o que nos remete também às dinâmicas de abastecimento de um navio para chegar a bom termo naquelas plagas. Observemos o quadro 5 .

O consignatário esteve realizando negócios entre Anamabû, Acara e Popo por 19 dias, e adquiriu um total de 49 pessoas entre crianças, adolescentes e adultos. Foram 14 adultos, 16 adolescentes e 20 crianças. Inferimos que pessoas jovens poderiam alcançar uma longevidade maior; bem alimentadas, se tornariam fortes e dispostas e, portanto, alcançariam um bom preço em breve tempo, sendo mais baratos no ato da compra na Costa da Mina. As crianças, se já fossem mais velhas, criadas/desmamadas, eram uma aposta a conseguir as mesmas vantagens dos jovens, além do que custavam menos ainda, eram mais fáceis de conduzir, ocupariam menos espaço e consumiriam uma quantidade menor de víveres. Certamente não era uma má opção. Essas reflexões talvez esclareçam a compra de dois terços de pessoas muito jovens em detrimento de um terço de adultos. É claro que especulamos; o mercado tem suas vicissitudes. Há possibilidade de uma oferta menor de pessoas adultas; certamente eram mais difíceis de serem capturados, ou outra qualquer dificuldade que pode ter provocado um maior número de pessoas mais jovens. $\mathrm{O}$ alto preço e a maior vantagem dos adultos davam-se por serem imediatamente incluídos no processo produtivo, ou seja, não impunha espera. O quadro de negócios que se desenhou entre Anamabû, Acara e Popo demonstra que havia uma preferência por tabaco em rolos em detrimento de outros produtos que eram usados para troca por escravos pela costa afora. Durante os dezenove dias de atividades mercantis, apenas tabaco em rolos e uma única ancora de aguardente foram transacionados. A aguardente talvez uma gentileza de José Francisco da Rocha a algum potentado ou amigo de labuta. Suas atividades nos portos esclarecem que em cada local havia um ritmo, pessoas e interesses diversos, que exigiam organização e experiência para os responsáveis pelo trato. O consignatário de José de Freitas Sacoto demonstra sua capacidade de ação, rede de relações e experiência no processo.

As descrições feitas pela historiografia sobre a Praça do Ajudá e seu entorno apontam o porto como sendo o mais importante do Golfo do Benim. A estimativa fica em torno de 400 mil escravizados, que foram de lá embarcados em direção ao Brasil nas primeiras décadas do Setecentos. Litoral de configurações geográficas complexas, não é propício para circulação e atracação de barcos. Ajudá ficava ao norte da laguna que corre paralela ao litoral, mais ou menos a cinco quilômetros da praia. No local não havia 


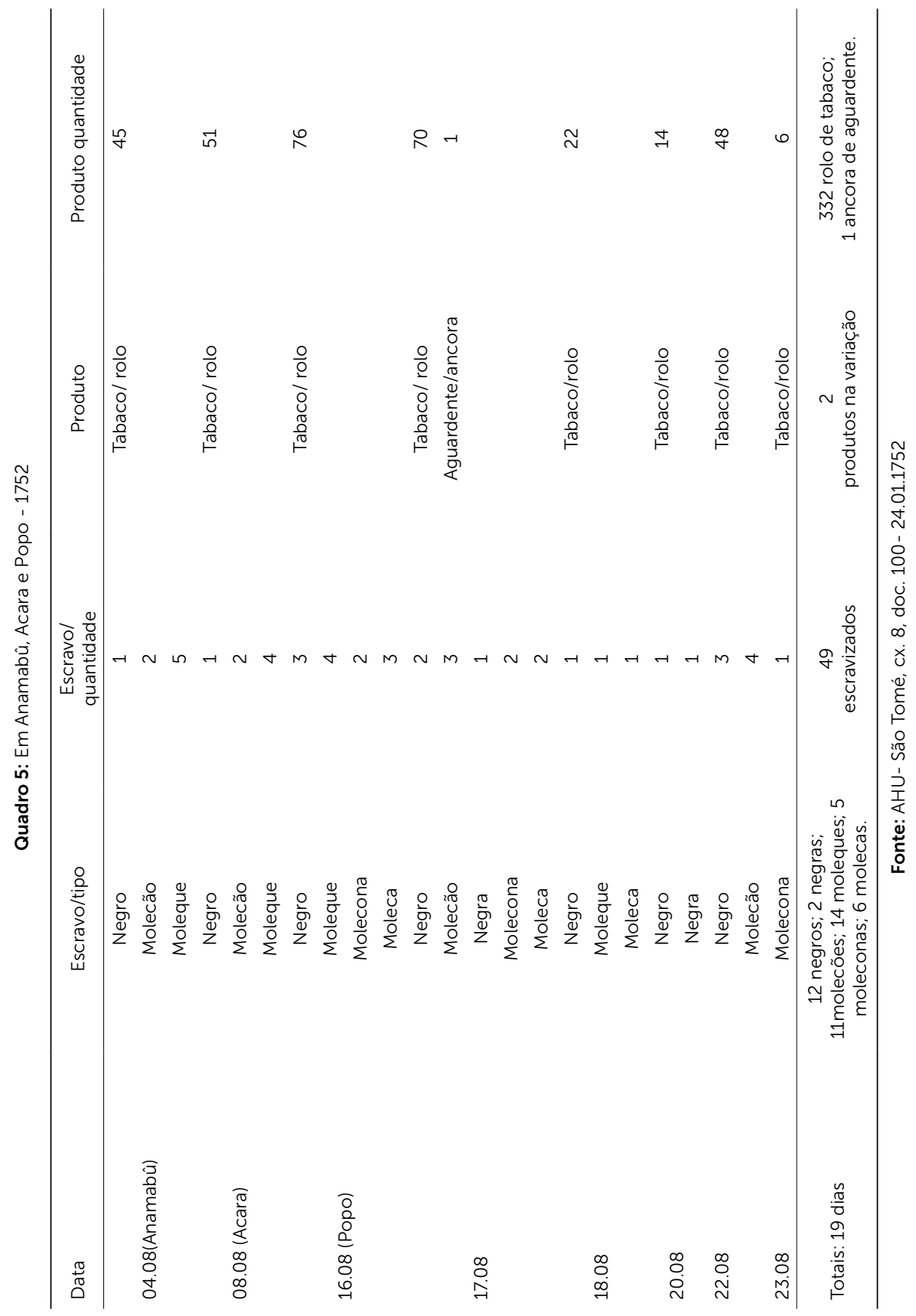


baías, nem bocas de rios profundas onde os navios pudessem ancorar com segurança. Tinham que ficar ao largo e, era à custa de grandes esforços e perigos que os seus escaleres e as canoas nativas atravessavam os bancos de areia que acompanhavam a linha da costa e as violentíssimas ondas que nelas arrebentavam (SILVA, 2004, p. 41).

No entanto, salientamos que os entraves físicos da área não formam empecilho, e cada vez mais embarcações procuraram o seu porto. O perigo provocado pelas ondas foi contornado pelos krus, barqueiros experientes contratados pelos capitães de navios, vindos com suas pequenas barcas da Costa do Ouro a oferecerem suas habilidades (SILVA, 2004, p.41).

Alberto da Costa e Silva descreve a região como densamente povoada e próxima a pequenos estados em conflito, o que o fez levantar a hipótese de que as guerras garantiram sempre um grande número de prisioneiros e consequentemente de cativos, o que compensou em Ajudá as dificuldades de ascender ao porto. Houve uma mistura de pessoas de características as mais diversas. A organização do trato e a presença de companhias de comércio junto a seus fortes, os depósitos particulares, comercialização organizada, práticas de negócios conhecidas e estáveis e um funcionário do rei do Daomé, Avogâ, para arbitrar diferenças. Compondo as vantagens e a infraestrutura, acrescentou o fato de que em Ajudá havia facilidade de abastecimento. Bons solos e chuvas permitiam regular atividade agrícola, sendo muitos os mandiocais, milharais, palmeirais, feijão, inhame, batata-doce, frutas, legumes e pimentas. Porcos, cabras e galinhas completavam a dieta dos marujos no porto, bem como a garantiam uma viagem farta na volta (SILVA, 2004, pp. 42-3). A seguir (Figura 1), apresentamos um mapa da praça que, mais do que um complemento para o entendimento da geografia da região, é uma descrição política e econômica local, divisão de poderes que se adensavam lado a lado, mas que também, dependendo das circunstâncias, se sobrepunham, situações às quais os negreiros deviam se adequar. No entorno dos fortes, cresciam os "bairros" que foram servindo de residência para os que se agregavam ao trato negreiro e às influências, fossem dos europeus, fossem dos poderes locais. Nosso olhar para a interpretação da documentação analisada esteve a esta cartografia conectada.

A galera chegou a Ajudá em 24 de agosto com apenas um dia de viagem, e fez novas despesas para realizar os negócios. A primeira providência foi adquirir uma bandeira para que fossem identificados o consignatário e seu navio. A bandeira era posta como sinal para localizar as barracas em terra durante as feiras, e custou 3 pânicos, que foram pagos ao rei do Omet (Daomé). Ao Avogâ e Caracû pagou-se pelas barracas 1 rolo de tabaco, 3 ancoras de aguardente e 1 côvado de seda. Quanto à a alimentação, principalmente para os escravos embarcados, ele registrou 2 barris de farinha, azeite, feijão, batatas, que lhe custaram 43 ancoras de aguardente. Mais 6 rolos de tabaco foram aplicados em sustento ao longo da viagem sem uma destinação definida. $O$ trabalho estafante de carga e descarga realizado pelas canoas e seus canoeiros foi também remunerado, e custou 280 côvados de seda e 8 rolos de tabaco; pagou por aluguel de casa e tronco 14 rolos de tabaco; com a tripulação da galera teve o dispêndio de 26 rolos; pagou ainda ao cirurgião pelo "curativo" de males que o acometeram (ao consignatário), mais 5 côvados de seda. 
กับ

यु

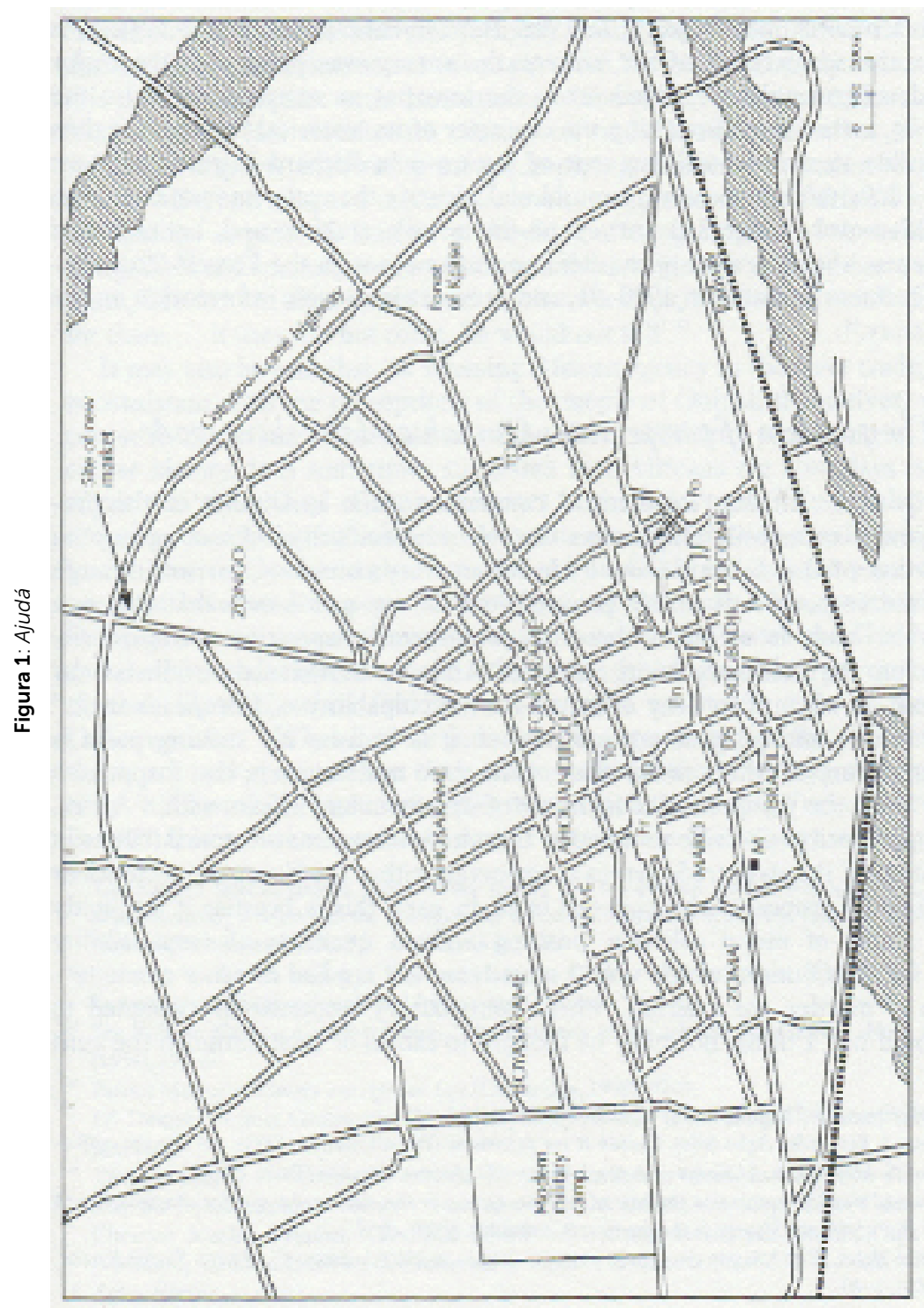

$\Rightarrow \frac{u}{\frac{C}{\pi}} \frac{}{0}$

일

过

는

(⿻)丨

西

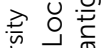

要

立

o

ㅎํㅇ

○े ü

훌 है

Oे

is

को

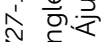

$\rightarrow \frac{1}{0}$

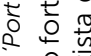

옹응

तु

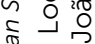

ชิ $I 1$

案它㶽

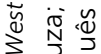

ㄱํㅇ 을

웡

तो 0

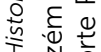

중

त्र

论走

\&ै

秀

용

Оิ

ᄃ 0 N

응 응 $\sum \frac{0}{0}$

宅它过嵌

“

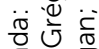
등

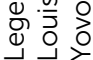


A importância dos canoeiros foi ressaltada em sua narrativa: transportavam cotidianamente as pessoas mais graduadas do navio à terra e da terra ao navio. Francisco José da Rocha não pernoitava em terra: seus aposentos na galera Aleluia da Ressurreição e Almas eram indiscutivelmente mais seguros que em qualquer casa ou barraca de acampamento. A guarda de valores no barco deveria ser constante e intensiva, exigindo a presença dos comandantes da missão, pois o ambiente era inseguro. Piratas, criminosos e facinorosos de todos os tipos circulavam nesses portos à procura de valores para afanar. Para garantir a movimentação de bens e pessoas do barco para terra, e vice e versa, gastou mais 3 rolos de tabaco e 3 ancoras de aguardente.

Com uma carga majoritariamente de tabaco e seda, foi fazendo negócios e trocas, adquirindo outros produtos, aqueles desejados pelos negociantes em terra. Nesse processo, outros agentes atlânticos vão emergindo e se conectando ao nosso personagem, o consignatário José Francisco da Rocha: um capitão holandês, o Amaral e seu fiel, foi referido com tanta intimidade, que nos parece conhecido de todos, um capitão inglês e muitos outros, todos negociantes com seus armazéns e barcos abastecidos preparados para as trocas.

No que tange aos artigos para troca, os holandeses saem na frente quanto ao quantitativo e à variedade de produtos que podiam oferecer. Trocaram-se o tabaco, aguardente, seda e pânicos por chita, riscado, panos brancos, algodão vermelho, saraças, cachimbos, lenços grossos, ferro em barras, ancoras e frascos de genebras, búzios, ouro em onças. Ou seja, de uma carga composta por quatro produtos ampliou-se para 17, incluindo-se os 13 adquiridos na costa. Esse era o processo: navegar com alguns produtos de interesses de compradores firmados na costa, trocá-los por aqueles que fossem interessantes para a população local, e aí por fim negociar comprando gente. O processo não era estanque, alguns vendiam produtos e outros gente? Não! Todos se arriscavam em todas as frentes. Era possível, ao mesmo negociante da Praça de Ajudá, trocar tabaco por cachimbos e vender escravos numa mesma operação.

Vejamos as reflexões que nos propõe o quadro 6.

A feira em Ajudá foi aberta no dia 03 de setembro, e as compras realizadas por José Francisco Rocha duraram sessenta dias neste porto. Ao todo ele comprou, segundo o Quadro 6 acima, 131 escravos que se dividiram entre 49 negros, 5 negras, 10 molecões, 15 moleques, 31 moleconas e 21 molecas. Nessa compra, cabe ressaltar o maior número de homens adultos, e na sequência de mulheres muito jovens. Observemos que mulheres jovens poderiam promover uma reprodução em cativeiro, o que se colocava muito interessante para senhores de escravos, fossem de amplos plantéis, fossem senhores de um quantitativo diminuto de cativos. A literatura aponta para o fato de as populações locais na África terem preferência para comercializar pessoas do sexo masculino, pois as mulheres desempenhavam um papel ativo no processo produtivo de víveres para o sustento das famílias e grupos (HAVIK, 2001, pp.18-23). As aquisições em Ajudá comprovam essa hipótese, pelo fato de ser o grupo de negras adultas diminuto em relação às demais aquisições; no entanto, ainda é preciso investigar como a comercialização de mulheres muito jovens interferiu anos à frente nos processos produtivos internos, em nosso caso da África Ocidental. 


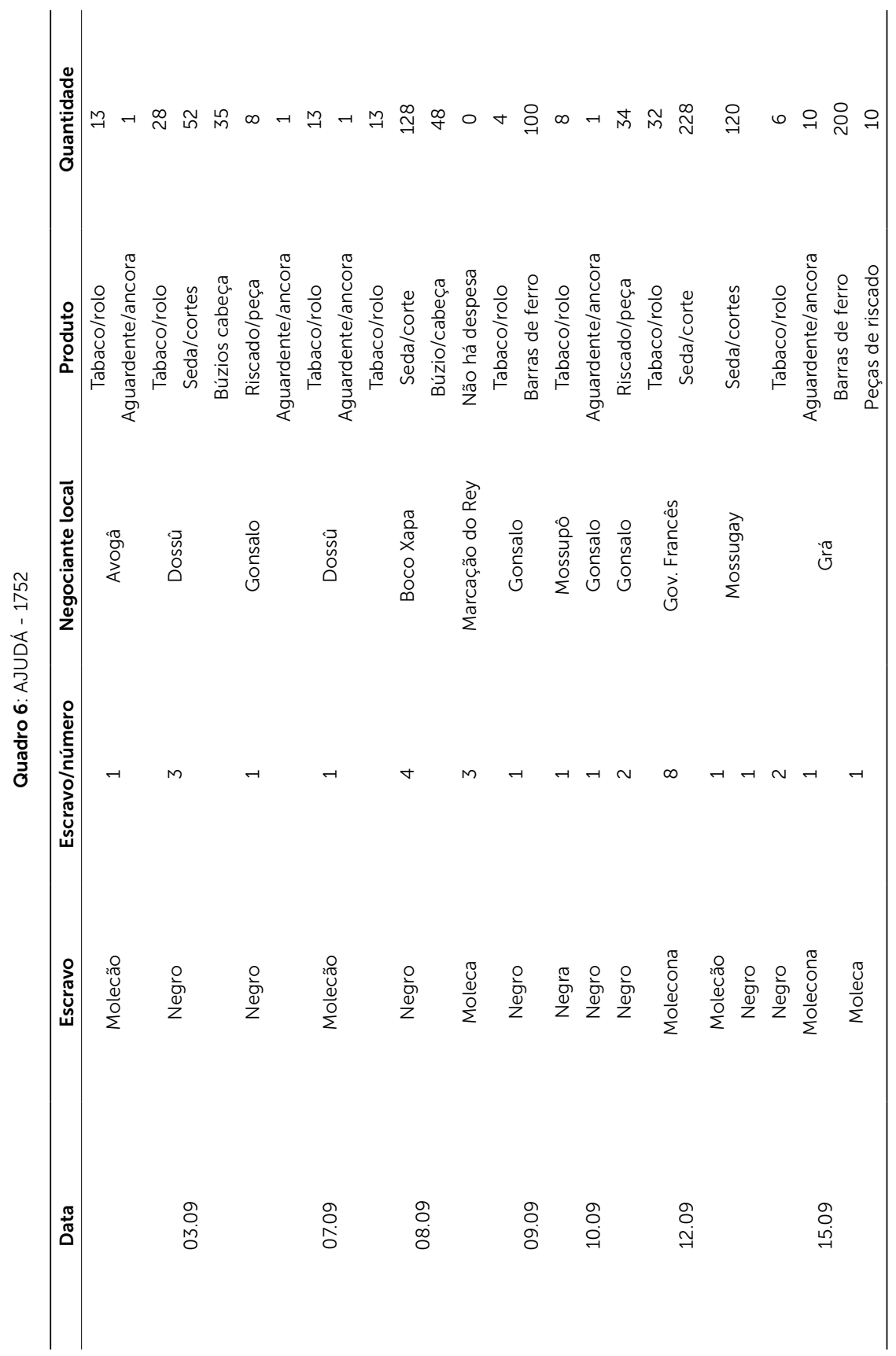




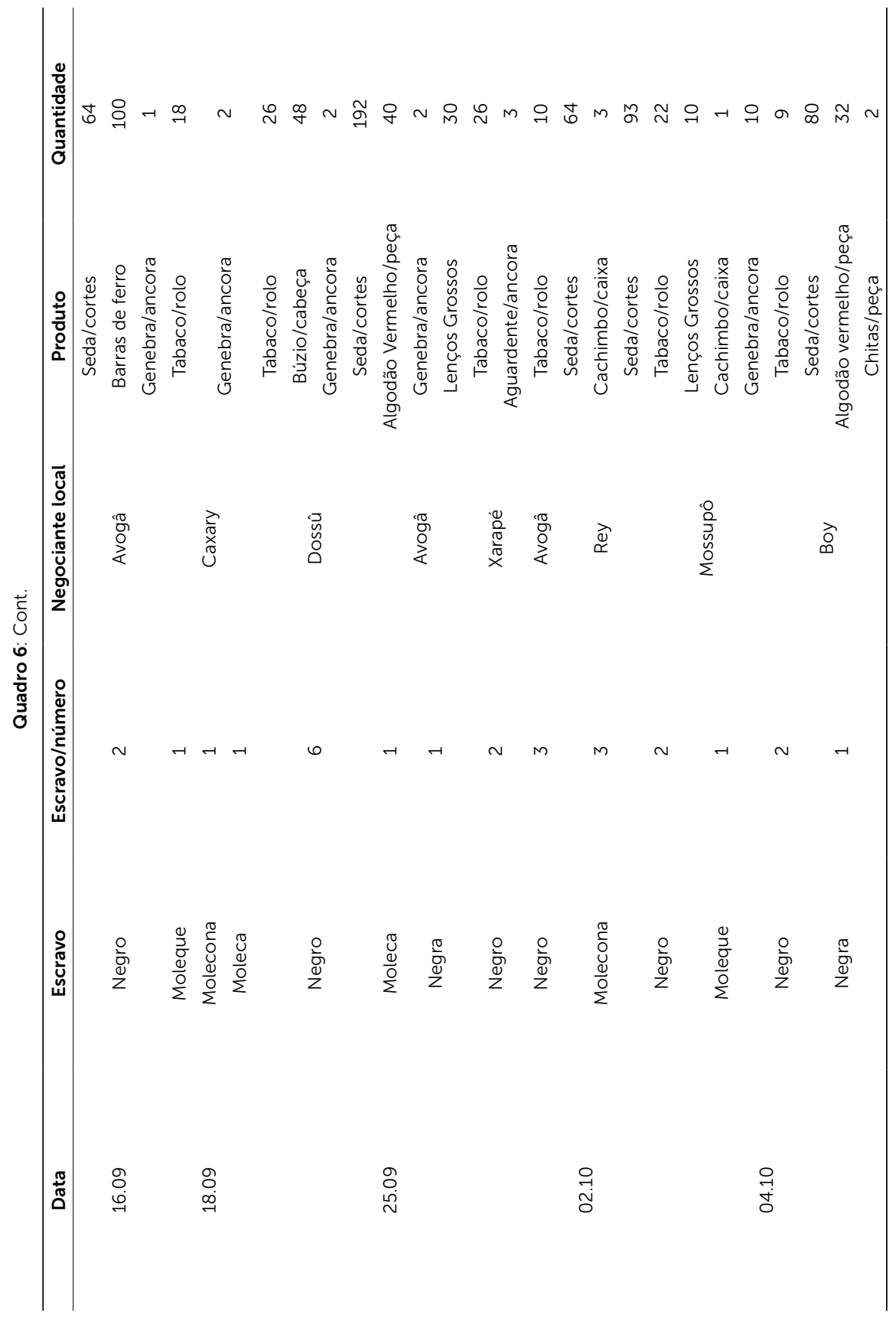




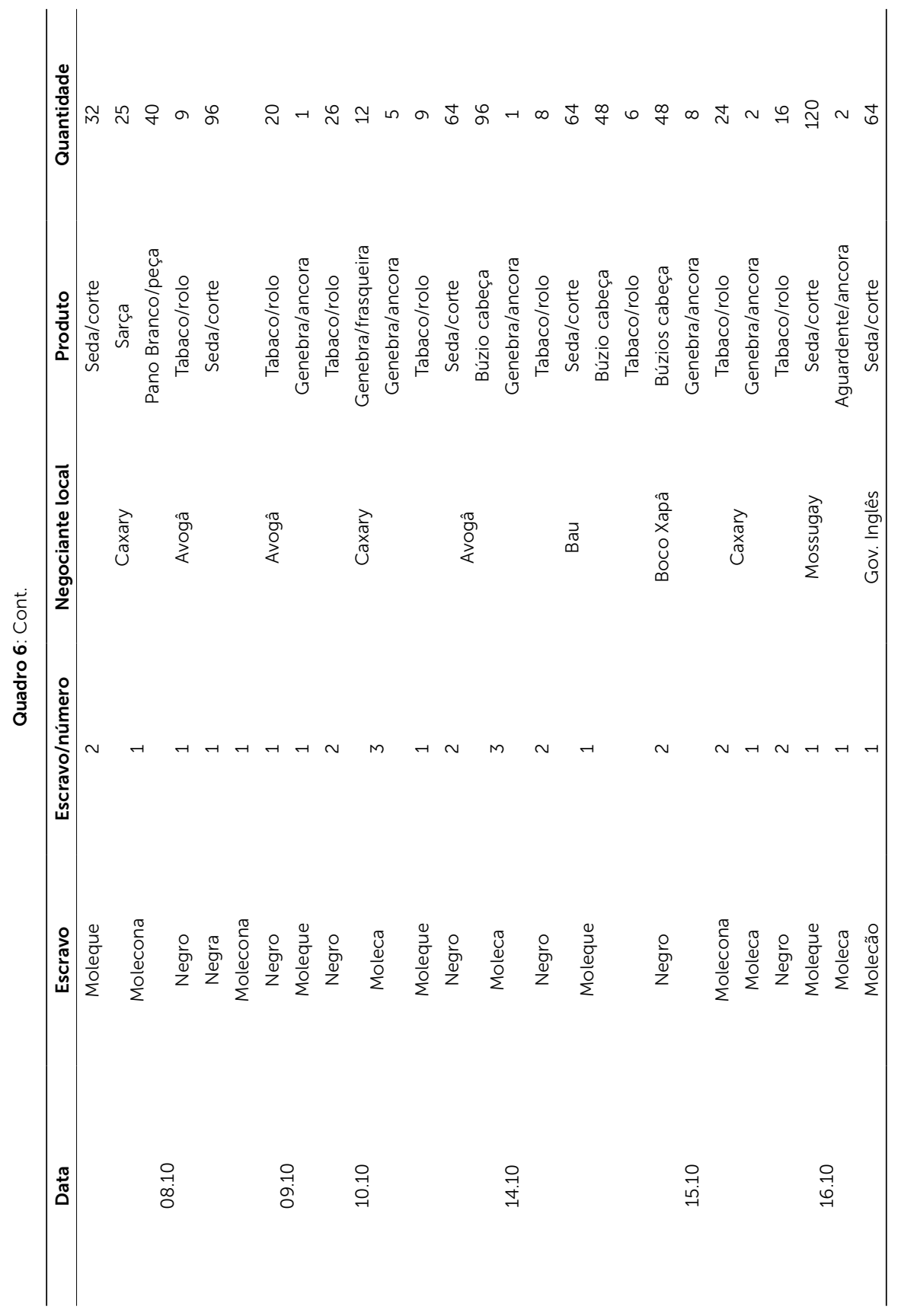




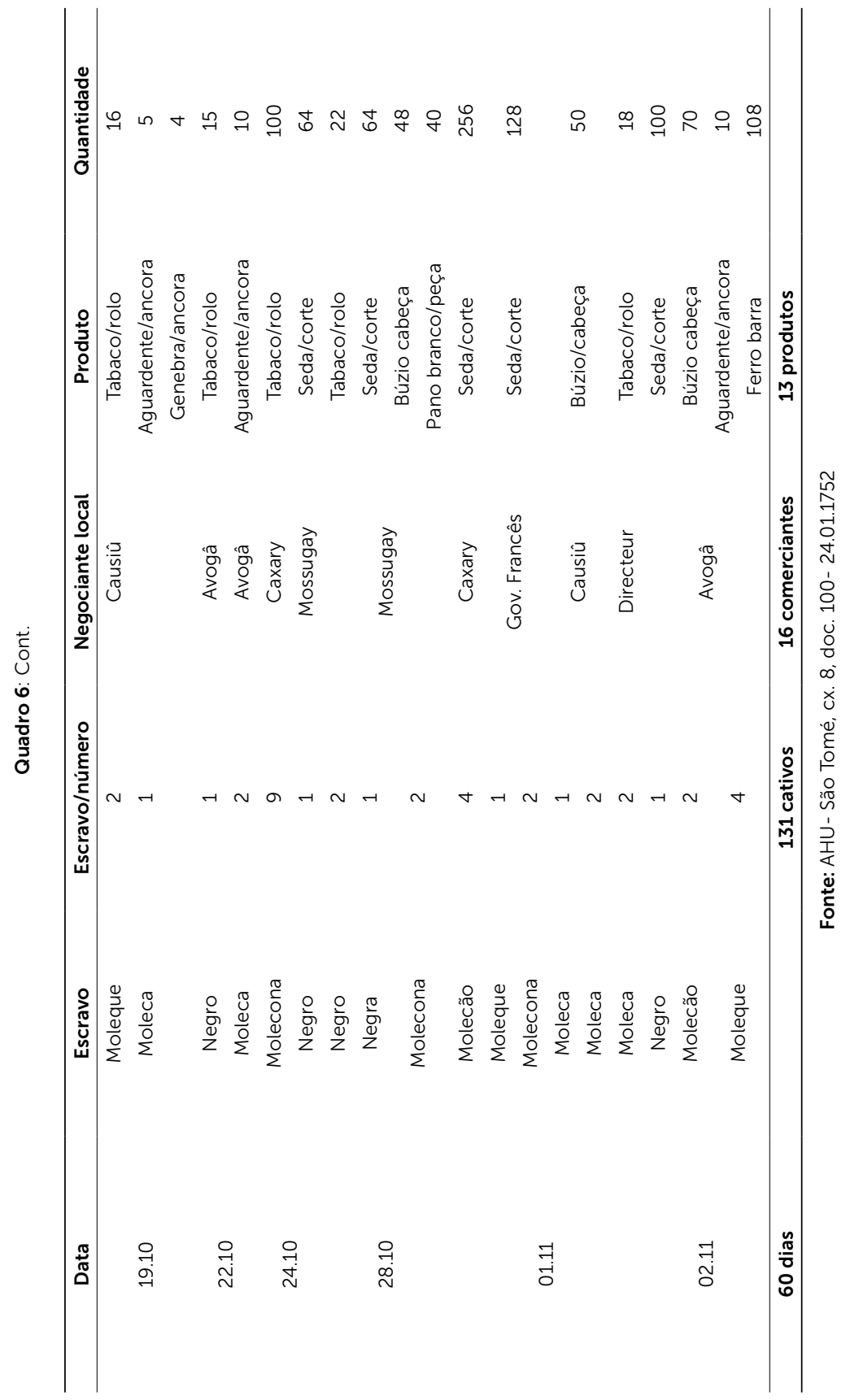


As atividades nesse porto demonstram uma malha complexa de negociantes estabelecidos localmente - que se mesclavam entre portugueses, ingleses, franceses, ou seja, estrangeiros - e um bom grupo de representantes de potentados locais e mesmo de comerciantes nativos ao continente. O consignatário estabeleceu negociações com 16 comerciantes estabelecidos na praça, dentre eles um português ou nascido no Brasil, o Gonsalo; um inglês, ao qual apenas denomina governador inglês; dois franceses, um denominado governador e outro de directeur. Os outros 12 receberam denominações das línguas locais e implícito - poderiam ser lugares de distinção, ou simplesmente o nome de pessoas, que são os seguintes: Avogâ, Dossû, Boco Xapá, Rey, Mossupô, Mossugay, Grá, Caxary, Xarapé, Boy, Bau, Causiû (CASTRO, 2002). ${ }^{21}$ Fica evidente em sua prestação de contas o quanto eram delicadas as relações nestes portos, devendo o consignatário tentar atender a demandas individuais dessas "autoridades". Refletindo sobre Uidá/Ajudá, no final do século XVIII, Nicolau Parés afirma que havia chefes nativos associados a cada um dos povos europeus que ali comerciavam e colocavam-se como línguas para intermediarem as transações, o que demonstra a complexidade da geografia política da Praça (2013, p. 330).

Suas anotações também esclarecem que a compra de pessoas se fazia no miudinho uma a uma; cada dia adquiria-se uma parte, da mesma forma que em cada porto. Em Ajudá, a quantidade de produtos foi muito mais variada que em Anamabû. A cesta de produtos incorporou, além do tabaco em rolos que continuou sendo a vedete das transações, mais 13 produtos, a saber, seda, riscado, algodão vermelho, lenços brancos, panos grossos, sarça ou saraça, chitas, cachimbos/caixas, genebras e aguardente em ancoras e/ou frasqueiras, barras de ferro, búzios. Era preciso ter conhecimento acerca dos produtos que seriam requisitados, uma sintonia com os gostos locais além da flutuação dos interesses ou " moda". Deveriam ser adquiridos na certeza de que seriam consumidos nas transações comerciais sem desperdício de dinheiro e energias. Otimizar era a regra, mesmo porque a carga da viagem de volta exigiria todo o espaço do navio, as sobras seriam nefastas. Se compararmos as transações efetuadas nos portos, perceberemos facilmente que cada lugar tinha demandas específicas, e o consignatário deveria estar preparado para atendêlas se desejasse realizar uma viagem bem-sucedida. De uma anotação simples, na qual basicamente estava registrado o tabaco negociado, transita-se para uma muito mais complexa, que registra minuciosamente 13 produtos e suas variações de apresentação a 16 negociantes estabelecidos no Ajudá, como demonstra o quadro anterior.

Aos 16 negociantes citados no quadro 6, somam-se mais 27, portugueses ou talvez brasílicos que também venderam escravos ao consignatário, e com os quais há o estabelecimento de relações de troca mais detalhadas em relação aos cativos. O cotidiano de compras apresenta-se estafante para o consignatário e cruel para os escravizados. Os negócios feitos na Costa da Mina são declarados minuciosamente e feitos em nome de José de Freitas Sacoto. Uma parte da escravaria adquirida foi assinalada com uma marca de sua carregação em partes diferentes do corpo, que remetiam a alguns dos negociantes da Costa, no sentido de talvez acertos financeiros posteriores, ou qualquer outra forma de cobrança entre as partes e entre praças. Havia uma geografia da carga. Ela era marcada segundo o seu destino na América e para qual proprietário era destinada. Era possível saber a origem do escravo na Costa, ou seja, de quem fora adquirido a partir da localização da marca no corpo dos cativos. Assim desde o embarque, os proprietários na América 
poderiam identificar o nome do negociante que vendeu os cativos de sua propriedade e em qual praça da Costa. Essa geografia era esclarecedora, pois poderia até informar as origens no interior da África, possíveis etnias, condições de saúde dos embarcados, etc. Cremos que os compradores recebiam no ato informações detalhadas sobre as pessoas adquiridas, repassando-as oralmente para os proprietários americanos. Dados preciosos que ficavam adormecidos e só em momentos muito específicos, como batismos, casamentos, óbitos, alforrias, elaboração de testamentos e inventários, vinham à tona de forma muito resumida, o que nos deixa antever por uma fresta uma dimensão quase totalmente perdida. Os senhores sabiam muito mais do que disseram.

Antes de a feira ser aberta a primeiro de setembro, negócios foram feitos com a Avogâ, adquirindo-se peças para o reverendo padre capelão João da Gama. Ele encomendou cinco escravos: um negro, dois moleques, duas moleconas. Foram marcados com a marca da carregação duas vezes no peito esquerdo. Nos dias subsequentes, foram sendo comprados muitos escravos, havendo mais descrições sobre os comerciantes da praça e a forma como os cativos eram identificados pelas marcas. Vejamos o quadro 7.

Marcados com ferro em brasa ainda na África, receberam neste ato os primeiros símbolos impostos pela experiência da diáspora. Era a entrada na sociedade escravista. Fica claro que esses rituais de marcação procuravam demonstrar aos escravizados/ as que eles/as estavam sob o jugo de outras pessoas (FERREIRA, CORZO, 2013, p. 131). Para a sociedade colonial, o corpo do escravo deveria ser registrado e observado para que se mantivesse na condição de despossuído. As marcas da escravidão relembravam ao escravizado/a cotidianamente que ele/a não se pertencia, mas pertencia a outrem, ou seja, era uma propriedade. As marcas se tornavam uma caracterização pública de escravidão e permitiam o reconhecimento. Tecnologia de controle, as marcas foram vetores das ações sociais do Estado e dos proprietários (FERREIRA, CORZO, 2013, pp. 130, 134).

Marcados os escravizados/as e concluídas as negociações, a galera retornou a Pernambuco com sua preciosa carga, mas antes passou e pagou direitos em São Tomé. Tomou José Francisco da Rocha a rota do retorno, com todo o cuidado para não se desviar das orientações de navegação há muito conhecidas. Ele sabia que teria que enfrentar 70 dias de viagem, e que a natureza é imprevisível. ${ }^{22}$ Cumprido o tempo e sem maiores transtornos, fundeou no porto de Pernambuco com uma carga de 307 escravos. 


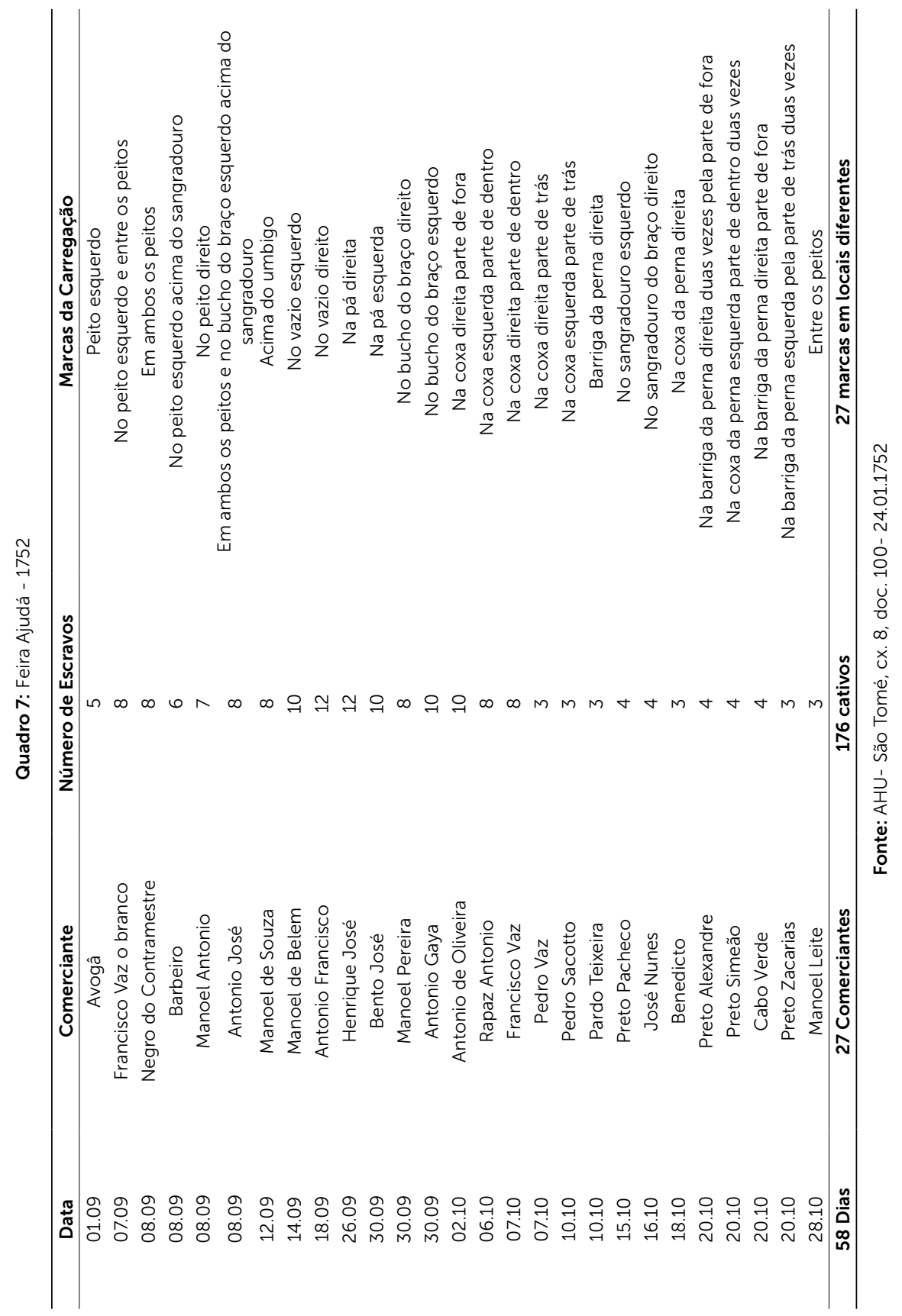




\section{REFERÊNCIAS}

ACIOLI, Vera Lúcia Costa. A Escrita no Brasil Colonial. Recife: Massangana, 2003.

ALENCASTRO, Luiz Felipe. O trato dos viventes: Formação do Brasil no Atlântico Sul. Séculos XVI e XVII. São Paulo: Companhia das Letras, 2000.

ARIĖS, Philippe. História Social da Criança e da Família. Rio de Janeiro: LCT, 1981.

AZEVEDO, Beatriz Libânio Bastos. O Negócio dos Contratos: contratadores de escravos na primeira metade do século XVIII. 2003. Dissertação (Mestrado em História)Universidade de São Paulo, 2013.

CASTRO, Yeda Pessoa. A língua mina-jeje no Brasil: um falar africano em Ouro Preto no século XVIII. Belo Horizonte: Fundação Pinheiro/Secretaria do Estado de Minas Gerais. 2002.

FERNANDES, João Azevedo. Selvagens bebedeiras: álcool, embriaguez e contatos culturais no Brasil colonial (século XVI-XVII). São Paulo: Alameda, 2011.

FERREIRA, Lúcio Menezes; CORZO, Gabino La Rosa. Símbolos não escolhidos: arqueologia das marcas a ferro em escravos de Cuba. In AGOSTINI, Camila. Objetos da escravidão: abordagens sobre a cultura material da escravidão e seu legado. Rio de Janeiro: 7 Letras, 2013.

FERREIRA, Roquinaldo. A arte de furtar: redes de comércio ilegal e mercado imperial ultramarino português (c. 1690-c.1750). In Na Trama das Redes: política e negócio no império português, séculos XVI-XVIII. Rio de Janeiro: Civilização Brasileira, 2010.

GOUVÊA, F. et all. O Antigo Regime nos Trópicos: a dinâmica imperial portuguesa (séculos XVI-XVIII). Rio e Janeiro: Civilização Brasileira, 2010.

HAVIK, Philip J. Matronas e Mandonas: parentesco e poder feminino nos rios da Guiné (século XVIII). In: PANTOJA, Selma (Org.). Entre Áfricas e Brasis. Brasília: Paralelo 15; São Paulo: Marco Zero, 2001, pp.13-34.

SILVA JR, Carlos da. "Ardas, Minas e Jejes, ou escravos de "primeira reputção": políticas africanas, tráfico negreiro e identidade étnica na Bahia do século XVIII". Almanack, 2016, n.12, Jan/Abr.

LAW, Robin. The Slave Coast of West África. Oxford: Oxford University Press, 1997.

LAW, Robin. Ouidah: The Social History of a West African Slaving 'Port' 1727-1892. Oxford: Oxford University Press, 2004.

LOPES, Gustavo Acioli. Negócio da Costa da Mina e o Comércio Atlântico: tabaco, açúcar, ouro e tráfico de escravos: Pernambuco (1654-1760). Tese. Universidade de São Paulo, 2008. 
LOPES, Nei. Enciclopédia Brasileira da Diáspora Africana. São Paulo: Selo Negro, 2011.

MARY DEL PRIORE em historia hoje.com. <http://historiahoje.com/?2695> Acesso em 16. agosto 2016

MELLO, José Antônio Gonsalves de. "Nobres e Mascates na Câmara do Recife, 1713-1738". Revista do Instituto Arqueológico, Histórico e Geográfico Pernambucano, Recife, v. 53, n. 1, 1981, pp. 151-189,

OSÓRIO, Helen. As elites econômicas e a arrematação dos contratos reais: o exemplo do Rio Grande do Sul. In: GOUVÊA, F. et all. O Antigo Regime nos Trópicos: a dinâmica imperial portuguesa (séculos XVI-XVIII). Rio e Janeiro: Civilização Brasileira, 2010. pp. 107138.

PARÉS, N. Cartas do Daomé. Afro-Ásia, 47, 2013, pp. 245-395

RAMBELLI, Gilson. A vida social ente o céu e o mar: os navios negreiros enquanto artefatos de escravidão. In AGOSTINI, Camila. Objetos da escravidão: abordagens sobre a cultura material da escravidão e seu legado. Rio de Janeiro: 7 Letras, 2013.

SAMPAIO, A.C. J. de. Os homens de negócio do Rio de Janeiro e sua atuação no quadros do Império Português (1701-1750). In: GOUVÊA, F. et all. O Antigo Regime nos Trópicos: a dinâmica imperial portuguesa (séculos XVI-XVIII). Rio e Janeiro: Civilização Brasileira, 2010. pp. 73-106.

SILVA, Alberto da Costa e. Francisco Félix de Souza, mercador de escravos. Rio de Janeiro: Nova Fronteira: Ed UERJ, 2004.

SOUZA, George F. Cabral de. Tratos, \& Mofatras: o grupo mercantile do Recife colonial (c.1654 - c.1759). Recife: Editora Universitária, 2012.

TRANSATLANTIC Slave Voyages. <http://www.slavevoyages.org/voyages14A6IXp2d> Acesso em 26.06.2016

\section{FONTES PRIMÁRIAS}

AHU- Avulsos de Pernambuco, Cx. 24, Doc. 2169.

AHU- Avulsos de Pernambuco, Cx. 31, Doc. 2863.

AHU- Avulsos de Pernambuco, Cx. 31, Doc. 2864.

AHU- Avulsos de Pernambuco, cx. 31, doc. 2865.

AHU- Avulsos de Pernambuco, Cx. 42, Doc. 3786.

AHU- Avulsos de Pernambuco, Cx. 61, Doc. 5221. 
AHU- Avulsos de Pernambuco, Cx.27, Doc. 245.

AHU- São Tomé, Cx. 8, Doc. 100.

AHU- São Tomé, Cx. 8, Doc. 100.

AHU-Avulsos de Pernambuco, Cx.87, Doc. 7129.

Anais da Biblioteca Nacional do Rio de Janeiro. V. 28., 1906.

Contrato que fez no Conselho Ultramarino com Domingos Rodrigues Bandeira da saída de escravos. X- BNPT-SC5604/15

Livro de Registro dos Contratos Reais do Conselho Ultramarino Cód. 297.

Mapas dos contratos Reais do Conselho Ultramarino Cód.1269

\begin{abstract}
Notas
1 Para o século XVIII, podemos contar com os trabalhos de Robson Costa "A ordem de São Bento e os escravos do santo, Pernambuco séculos XVIII e XIX" (2012); Gustavo Acioli Lopes, "Negócio da Costa da Mina e o comércio Atlântico: tabaco, açúcar, ouro e tráfico de escravos: Pernambuco 1654-1760"(2008); M. Menz, "A Companhia de Pernambuco e Paraíba e o tráfico de escravos para Angola 1759-1775/80" (2013); Ana Emília Staben, "Negócio dos escravos: comércio de cativos entre a Costa da Mina e a capitania de Pernambuco ( 1701-1759)"(2008); Felipe Melo, "O negócio de Pernambuco: financiamento, comércio e transporte na segunda metade do século XVIII"(2017). Para abordagens sobre o século XIX, apontamos Peter Eisenberg, com "Modernização de Mudança: a indústria açucareira em Pernambuco 1840-1910"(1977); Marcus Carvalho, com " Liberdade: rotinas e rupturas do escravismo no Recife (1822-1850) (2001); O Alufá Rufino: tráfico, escravidão e liberdade no Atlântico negro (c. 1822-c.1853) (2010), obra de grande repercussão dividida entre João José Reis e Fávio Gomes, além de vários artigos publicados em revistas especializadas como "Trabalho, cotidiano, administração e negociação numa feitoria do tráfico no rio Benim em 1837" (2016), "Os desembarques de cativos africanos e as rotinas médicas no Porto do Recife antes de 1831"(2016), "O Patacho Providência um navio negreiro: política, justiça, e redes depois da lei antitráfico de 1831"(2104), "O desembarque nas praias: o funcionamento do tráfico de escravos depois de 1831"(2102), entre outros. Também tratou do tema Valéria Gomes Costa com "O Recife nas rotas do Atlântico negro: tráfico, escravidão e identidade no oitocentos" (2013); Aline de Biase escreveu "De "Angelo dos Retalhos" a visconde de Loures: a trajetória de um traficante de escravos (1818-1858)(2015); Amanda Barlavento, "A trajetória de vida do Barão do Beberibe, um traficante de escravos no Império do Brasil (1820-1855)" (2106).
\end{abstract}

2 "O desembarque do menino conguês Camilo em pernambuco, ou, o comércio transatlântico de crianças escravizadas depois de 1831". Anais 8 Encontro Escravidão e liberdade no Brasil Meridional. http://www.escravidãoeliberdade.com.br

3 Códice 1269 -AHU, Coleção Códice 1, folha 0451. AHU- São Tomé, Cx. 8, Doc. 100- 24.01.1752.

4 Há uma historiografia consolidada sobre os contratadores e suas práticas. Para um maior aprofundamento entre as obras mais recentes ver (OSÓRIO, 2010, pp. 107-138); (SAMPAIO, 2010, pp. 73-106); (GOUVÊA, 2010).

5 Livro de Registro dos Contratos Reais do Conselho Ultramarino 2. V., (1731-1753), Cód. 297, p. 54.

6 Mapas dos contratos Reais do Conselho Ultramarino - Discurso -1. V.,(1641-1758) Cód.1269, p.2-9

7 AHU- Avulsos de Pernambuco, Cx. 42, Doc. 3786, 12.09.1731

8 Informação Geral da Capitania de Pernambuco - 1749, In: Anais da Biblioteca Nacional do Rio de Janeiro. V. 28., 1906. p. 407-422

9 Idem

10 ANTT- Habilitação da Ordem de Cristo. Inácio de Freitas Sacoto, letra I, m.44,n.5.

$11 \mathrm{AHU}$ - Avulsos de Pernambuco, Cx. 24, Doc. 2169. Os homens que subscreveram as letras foram: Manuel Antunes Correia 3:189\$665; Manuel Correia de Souza 505\$750; Lionardo Lopes 7\$000; Cosme Pereira França 4:921\$590; Capitão Zacarias Brito 458\$488; Ângelo Ferreira da Costa $333 \$ 666$. 
12 AHU- Avulsos de Pernambuco, Cx.27, Doc. 245. Num somatório de ouro, açúcar e letras foi enviada a quantia de 2:00\$376 rs. A letra foi assinada pelo já citado Capitão Zacarias de Brito Tavares considerado um dos primeiros homens de negócio da praça no valor de $400 \$ 000$ rs.

13 AHU- Avulsos de Pernambuco, Cx. 31, Doc. 2863. Para aqueles que não pagassem os direitos nas ilhas, a pena seria a de pagar três vezes nos portos do Brasil.

14 AHU- São Tomé, Cx. 8, Doc. 100- 24.01.1752. Côvado: 66 centímetros; Pipa ou Barrica: 21 a 25 Almudes que por sua vez são 31 litros e 94 decalitros; Ânforas ou âncoras: vasos abaolados com alças laterais nos quais se transportava bebidas. Podem ser descritas como medida de líquidos correspondente a 10 e 1/2 galões. É possível ainda encontrar "ancorestinha pequena" ou "ancora grande", estas baseadas nas medidas dos galões de vinho: o de 3,785 litros e o galão imperial de 4,546 litros. Também são descritas com a capacidade de mais ou menos 26 litros. ACIOLI, Vera Lúcia Costa, A Escrita no Brasil Colonial, Recife: Massangana, 2003. p. 307. PARÉS, N. Cartas do Daomé. Afro-Ásia, 47 (2013), pp. 251. Aguardente é o produto transportado. Fabricado com o caldo da cana difere da cachaça ou jeribita produzida a partir do mel que escorria das formas de barro em que o açúcar descansava. FERNANDES, João Azevedo, Selvagens bebedeiras: álcool, embriaguez e contatos culturais no Brasil colonial (século XVI-XVII), São Paulo: Alameda, 2011. Hoje aguardente é toda a bebida obtida por fermentação e destilação, assim a cachaça é uma aguardente obtida da cana.

15 Discordamos de uma historiografia que afirma: "a maior parte dos negreiros adquiriam suas cargas em um, talvez dois, portos de embarque". JR, Carlos da Silva, "Ardas, Minas e Jejes, ou escravos de "primeira reputção": politicas africanas, tráfico negreiro e identidade étnica na Bahia do século XVIII," Almanack, n.12, Jan/Abr, 2016.

16 Não encontramos indicativos de que a Galera carregava ouro do Brasil, embora saibamos que há uma literatura bem fundamentada que aponta a presença de muito ouro do Brasil para comércio na Costa da Mina. Sobre a questão ver LAW, Robin. The Slave Coast of West África. Oxford: Oxford University Press, 1997. FERREIRA, Roquinaldo. A arte de furtar: redes de comércio ilegal e mercado imperial ultramarino português (c. 1690-c.1750), In: Na Trama das Redes: política e negócio no império português, séculos XVI-XVIII. Rio de janeiro: Civilização Brasileira, 2010. pp. 203-240. LOPES, Gustavo Acioli. Negócio da Costa da Mina e o Comércio Atlântico: tabaco, açúcar, ouro e tráfico de escravos: Pernambuco (16541760).2008. Tese (Doutorado em História)-Universidade de São Paulo, 2008.

17 Quartiamento ou daxa: taxa de $10 \%$ paga sobre as mercadorias a bordo dos navios aos holandeses. SILVA Jr. Carlos da. Ardas, Minas e Jejes, ou escravos de "primeira reputação ": políticas africanas, tráfico negreiro e identidade étnica na Bahia do século XVIII. Almanack, n.12, Jan/Abr., 2016.

18 Cauri: Búzios ou molusco univalve, outrora usado como moeda em várias regiões do continente africano. Há algumas denominações para a Moeda da Costa: Cabeça pequena (2.000 búzio ou $1 \$ 000$ réis); Cabeça grande (4.000 búzios ou $2 \$ 000$ réis). PARÉS, Op. Cit., p. 235; LOPES, Nei. Enciclopédia Brasileira da Diáspora Africana. São Paulo: Selo Negro, 2011. p. 185

19 AHU- São Tomé, Cx. 8, Doc. 100- 24.01.1752

20 /dem.

21 Segundo Yeda Pessoa, o grupo linguístico ewe-fon ou gbe da família Kwa foi o que predominou nos falares da Costa da Mina. É provável que estas denominações estejam ligadas às línguas locais como a lorubá. Para alguns historiadores, já há uma denominação/significação não muito precisa, mas que pode elucidar o contexto. Avogâ/ Yovogan pode significar pano para cerimônia funerária; conjunto musical dos minas; potentado local/representante do rei do Daomé; uma dança tradicional do Daomé; nome de família do Benim. Dossou pode significar vendedor/mercador; Boco denominação para crianças que haviam nascido com o cordão umbilical enrolado no pescoço, e Xapa o nome da pessoa. Grá ou Grau pode ser referência ao título máximo de chefe militar que comandava a ala direita do exército daomeano. Agradecemos à Marisa Soares a interlocução sobre esta questão.

22 As embarcações que faziam a rota Costa da Mina /Pernambuco gastavam o dobro do tempo do consumido em uma viagem Luanda/Pernambuco. Ou seja, 70 dias em detrimento dos 35 para Angola. AHU- Avulsos de Pernambuco- Cx.87, Doc. 7129, 12.11.1758.

Suely C. Cordeiro de ALMEIDA. Professora Doutora. Departamentos de História e do Programa de Pós-Graduação em História da Universidade Federal Rural de Pernambuco. Rua Manuel de Medeiros s/n, Dois Irmãos, Recife, PE, Brasil. Nossos agradecimentos ao CNPq pelo apoio financeiro dado a esta pesquisa. 